\title{
IMPLIKASI PERDEBATAN TENTANG BASMALAH ATAS KEMUTAWATIRAN AL-QUR`AN
}

\author{
Moh. Zahid \\ (Jurusan Syari ah STAIN Pamekasan, Jl. Raya Panglegur Km. 4, \\ Email: z4hid.4lfawari@gmail.com)
}

\begin{abstract}
Abstrak:
Para ulama sepakat bahwa pencantuman seluruh ayat dalam mushaf al-Qur'an didasarkan pada riwâyat yang mutawâtir, sehingga terjamin keasliannya (qath '̂̀ wurûd âyi al-Qur'ân). Demikian halnya pada lafal basmalah yang terdapat pada awal surah. Oleh karena itu, madzhab Mâlikî menolak menetapkan basmalah sebagai ayat al-Qur`an, karena adanya beberapa riwâyat ahâad yang menginformasikan dua hal berbeda, yaitu bagian dari al-Qur`an dan bukan bagian darinya. Sesungguhnya, riwâyat ahâa tidak dapat digunakan untuk memasukkan sebuah teks menjadi ayat al-Qur'an atau juga menolaknya. Sementara pandangan mayoritas ulama tidak hanya didasarkan pada beberapa riwayat ahâd yang menyatakan bahwa basmalah merupakan ayat al-Qur'an. Fakta kesejarahan pada proses jam`u al-Qur'ân (penghimpunan al-Qur`an) sejak masa Rasulullah, masa Khalifah Abû Bakr sampai pembakuan al-Qur'an pada masa Khalifah 'Utsmân bin `Affân menegaskan bahwa para sahabat tidak akan memasukkan atau menolak suatu ayat, jika hanya didasarkan

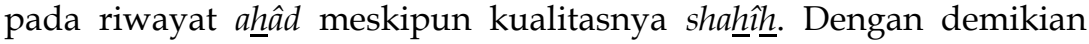
penetapan lafal basmalah sebagai ayat al-Qur`an, tidak hanya didasarkan pada riwayat ahâad, tetapi didukung dengan ijmâa sahabat terhadap keberadaan Mushhaf Utsmânî atau dikenal dengan sebutan sumber periwayatan mutawâtir 'amalî.
\end{abstract}

\begin{abstract}
:
The ulama agreed that the inclusion of all sentences in the Qur'an must be based on riwâyat which is mutawâtir, so the truth can be guaranteed (qath 'î wurûd âyi al-Qur'ân). It also happened to the word basmalah which always comes in the beginning of the Surah. Therefore, Maliki school refused to state that basmalah as the Qur'an's sentence, because of the existence of some riwâyat ahâd which informed two different things: it is a part of the Qur'an and it is not. Actually riwâyat ahâd cannot be used to include a text to be a sentence of the Qur'an or to refuse it. While the majority of ulama's point of
\end{abstract}

al-1hkâm Vol.10 No.2 Desember 2015

DOI: http://dx.doi.org/10.19105/ihkam.v10i2.721 
Implikasi Perdebatan tentang Basmalah

view is not only based on some ahâad histories which stated that basmalah is a sentence of the Qur'an. The history facts in the process of jam 'u al-Qur'ân (the gathering of the Qur`an) from the era of the prophet/Rasulullah, the year of Abû Bakr to the standardization of the Qur`an in the year of Utsmân bin 'Affân confirmed that the companions of the prophets would never include or refuse a sentence, if it was only based on the ahâd history although its quality was shahîh. Therefore, the determination of the word of basmalah as a statement of the Qur'an, should not be based on the ahâd history only, but also supported with ijmâ of the companions to the existence of Mushhaf Utsmânî or which is known as the source of history of mutawâtir amalî.

\section{Key Words:}

Mutawâtir, Basmalah, Qath î al-Wurûd, Zhannî al-Wurûd

\section{Pendahuluan}

Dua ulama besar, al-Zarkasyî dan al-Suyûthî, menegaskan bahwa para ulama sepakat bahwa periwayatan ayat-ayat al-Qur`an seluruhnya mutawâtir, ${ }^{1}$ sehingga menjadi jaminan keotentikannya (qath î wurûd al-Qur'ân). Hal demikian bermakna bahwa ayat-ayat alQur`an diriwayatkan dengan melibatkan umat Islam secara massif dari satu generasi ke generasi berikutnya, sehingga dapat tercegah adanya tindakan penyelewengan terhadapnya seperti penghilangan, pengurangan atau penambahan ayat-ayatnya. ${ }^{2}$ Periwayatan al-Qur'an secara mutawâtir, menurut banyak pakar, merupakan salah satu kreteria dalam pendefinisiannya. Semisal definisi yang disampaikan oleh Muhammad ibn 'Alî al-Shâbûnî bahwa: "Al-Qừan adalah firman Allah yang bernilai mukjizat, diturunkan kepada Nabi dan Rasul penghabisan dengan perantaraan Malaikat yang terpercaya, Jibril, tertulis dalam Mushaf yang dinukilkan kepada kita secara mutawâtir, membacanya merupakan ibadah, yang dimulai dari surah al-Fâtihah dan diakhiri dengan surah al-Nâs."3

1Badr al-Dîn al-Zarkasyî, al-Burhân fí 'Ulûm al-Qur'ân, Juz 2, Cet. ke-1, (Beirut: Dâr alKutub al-'Ilmiyyah, 2007), 74. Lihat juga Jalâl al-Dîn al-Suyûthî, al-Itqân fî 'Ulûm alQur'ân, (Beirut, Libnân: Dâr al-Kutub al-'Ilmiyyah, 2010), 119.

Ibid.

3Muhammad ibn 'Ali al-Shâbûnî, at-Tibyân fi 'Ulûm al-Qur'ân, (Karachi: Qadîmî Kutub Khânah, t.t.), 8. Demikian juga definisi yang disampaikan oleh Muhammad 
Sesungguhnya setelah selesainya pembukuan al-Qur`an pada masa pemerintahan Khalifah Usman, para Sahabat telah sepakat terhadap ayat-ayat al-Qur'an yang termaktub dalam Mushhaf 'Utsmânî itu dan tidak ada seorang pun dari sahabat yang berkeberatan atau menyangkalnya. Kesepakatan ini tak akan terjadi kecuali karena pengumpulan ini sifatnya tawqîfi. Sebab bila seandainya berdasarkan ijtihâd, maka para sahabat tentu akan berpegang teguh pada pendapatnya masing-masing. ${ }^{4}$

Dengan demikan, seharusnya keberadaan ayat-ayat al-Qur`an tidak dipersoalkan lagi. Namun para ulama masih berbeda pendapat mengenai keberadaan dan jumlah ayat al-Qur`an. Dari sisi jumlah ayat-ayat al-Qur`an, al-Zarqânî menyebutkan bahwa para ulama sepakat pada angka 6200, tetapi berbeda pada angka puluhan dan satuannya, ${ }^{5}$ dengan rincian sebagai berikut: (1) ulama Madinah awal, yakni pendapat Nâfi sebanyak 6217 ayat, (2) ulama Madinah akhir; yang disandarkan pada pendapat Abî Syaibah sebanyak 6214 ayat, dan Abû Ja 'far sebanyak 6210 ayat, (3) ulama Makkah sebanyak 6220 ayat, (4) ulama Kûfah, yakni pendapat Hamzah al-Ziyât sebanyak 6236 ayat, (5) ulama Bashrah sebanyak 6204 ayat, 6205 ayat dan 6219

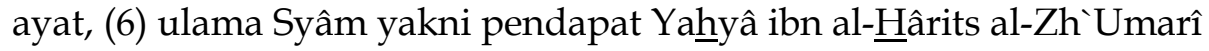
sebanyak 6226 ayat. $^{6}$

Perbedaan pendapat di atas bertolak dari perbedaan mengenai (1) penentuan fâshilah dan ra's al-âyat, ${ }^{7}$ dan (2) keberadaan basmalah

\footnotetext{
'Abd al-'Azhîm al-Zarqânî, Manâhil al-'Irfân fî̀ 'Ulûm al-Qur'ân, Juz 1, Cet. ke-1 (Beirut: Dâr al-Kitâb al-'Arabî, 1995), 21. Baca juga Mushthafâ Dîb al-Bigâ' dan Muhyî al-Dîn Dîb Mastû, al-Wâdhih fî 'Ulûm al-Qur'ân, Cet. ke-2, (Dimasyq: Dâr al-'Ilm alKatîb dan Dâr al-'Ulûm al-Insâniyyah, 1998), 23

"Al-Zarqânî, Manâhil al-'Irfân fì 'Ulûm al-Qur'ân, juz 1, hlm. 355 - 357. Mannâ' alQaththân mendukung pendapat yang menyatakan bahwa urutan ayat dan surah dalam al-Qur’an merupakan tauqifí Rasûlillâh Saw. Baca al-Qaththân, Mabâhits fî 'Ulûm al-Qur'ân, (al-Qâhirah: Maktabah Wahbah, t. t), 137-138.

5Baca al-Zarqânî, Manâhil al-'Irfân, Juz 1, 336.

'Informasi lebih detail dapat dibaca juga dalam `Abd al-Fattâh ibn `Abd al-Ganî al-

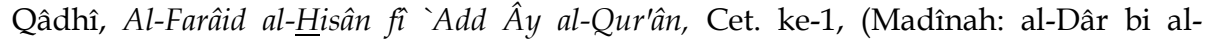
Madînah al-Munawwarah, 1404 H), 25-27.

${ }^{7}$ Fâshilah adalah istilah yang diberikan kepada kalimat yang mengakhiri ayat dan merupakan akhir ayat. Sedangkan $\mathrm{ra}^{\prime}$ s al-ayat adalah akhir ayat yang padanya diletakkan tanda fashl (pemisah) antara ayat yang satu dengan ayat yang lain. Fâshilah ini terkadang berupa ra's al-ayat dan terkadang tidak. Dengan demikian, setiap ra's al-
} 
Implikasi Perdebatan tentang Basmalah

(bacaan bism Allâh al-Rahmân al-Rahîm) yang terdapat pada setiap awal surah kecuali al-Barâ'ah [9]. Perbedaan pendapat tentang penentuan fâshilah dan ra's al-âyah hanya berkisar mengenai cara penghitungan ayat al-Qur`an .8 Perbedaan pendapat mengenai hal ini tidak sampai mempersoalkan keabsahan ayat-ayatnya. Berbeda halnya perbedaan pendapat mengenai keberadaan basmalah yang akan berimplikasi tidak hanya pada jumlah ayat pada setiap surah tetapi juga pada keabsahan lafal basmalah sebagai ayat al-Qur'an atau pencantumannya hanya semata-mata untuk tabarruk (mengharap keberkahan). ${ }^{9}$ Masih adanya perbedaan pendapat mengenai keberadaan lafal basmalah menunjukkan bahwa pencantumannya, oleh sebagian ulama, dinilai belum pasti (zhannî al-wurûd), yang pada akhirnya keaslian al-Qur`an (qath î̀ wurûd âyi al-Qur'ân) juga turut dipertanyakan.

Artikel ini menguraikan dua permasalahan pokok, yaitu: 1) kenapa lafal basmalah pada awal surah masih diperdebatkan keberadaannya sebagai ayat al-Qur`an; dan 2) apakah perdebatan mengenai keberadaan lafal basmalah pada awal surah menggugurkan keharusan periwayatan ayat-ayat al-Qur`an secara mutawâtir.

ayat adalah fâshilah dan tidak setiap fâshilah adalah ra's al-ayat. Baca Mannâ' alQaththân, Mabâhits al-'Irfân, 145.

${ }^{8}$ Istilah ayat berasal dari bahasa Arab, âyah digunakan beberapa kali oleh al-Quran sendiri dengan berbagai arti. Diantaranya, berarti tanda (Q.S. al-Hijr 15: 77; al-Nahl 16: 11, 13, 65, 67, dan 69; al-Baqarah 2:248); mukjizat (Q.S. al-Baqarah 2:211); `ibrah atau pelajaran (Q.S. Hûd 11:102, 103 dan al-Furqân 25:37); sesuatu yang menakjubkan (Q.S. al-Mu'min 40:50); dan bukti atau dalil (Q.S. al-Rûm 30:20-24). Secara terminologis, ayat merupakan sekelompok kata yang mempunyai permulaan dan akhir yang berada dalam suatu surah al-Qur`an. Al-Zarqânî, Manâhil al-'Irfân, Jilid 1, 350. Batasan ini didukung oleh al-Qur`an sendiri, semisal Q.S. Yûsuf 12:1: "Alif lâm râ'. Ini adalah ayat-ayat kitab (al-Qur 'an) yang nyata (dari Allah)". Sedangkan panjang pendeknya surah-surah al-Qur'an dikelompokkan menjadi beberapa kelompok. Althiwâl, yaitu tujuh surah yang panjang yang terdapat pada permulaan al-Mush $\underline{h} a f$, yaitu Q.S. al-Baqarah [2], Âli 'Imrân [3], al-Nisâ' [4], al-Mâ'idah [5], al-An 'âm [6], alA 'râf [7] dan al-Anfâl [8]). Al-mi' ûn adalah nama yang diberikan kepada surah-surah yang ayatnya seratus atau lebih sedikit. Al-matsâni, dikenal sebagai surah-surah yang jumlah ayatnya yang tidak mencapai 100 ayat. Sedangkan al-mufashshal adalah surahsurah yang lebih pendek. Disebut dengan mufashshal karena banyak fashl (pemisah) yakni basmalah. Baca al-Suyûthî, al-Itqân, 352.

9 Perbedaan pandangan mengenai keberadaan lafal Basmalah pada awal surah dapat dibaca pada Muhammad 'Alî al-Shâbûnî, Tafsîr Âyâtil Ahkhâm min al-Qur'ân, Juz 1, Cet. ke-1, (Beirut: Dâr al-Qur'ân al-Karîm, 2004), 33-34. 
Permasalahan tersebut, dikaji melalui penelitian kepustakaan (library research), atau disebut juga kajian literatur, kajian teori, atau studi pustaka, ${ }^{10}$ yaitu meneliti pelbagai rujukan yang relevan dengan kajian tentang perdebatan penetapan lafal basmalah sebagai ayat alQur`an dengan menggunakan metode dokumentasi. Pelbagai rujukan dipilah menjadi dua bagian, (1) sumber data primer, yaitu sumber data utama atau data-data yang relevan yang menjadi acuan pokok penelitian ini, antara lain: al-Qur`an al-Karim, kitab-kitab Hadits, kitab ulumul Qur`an dan tafsir, dan (2) sumber data sekundernya, yaitu berupa rujukan lainnya yang memiliki keterkaitan dengan pokok bahasan penelitian ini.

Data yang diperoleh dikaji dan diteliti secara mendalam. Analisis komprehensif dilakukan sehingga mampu memberikan gambaran terjadinya perdebatan itu sebagai akibat dari perbedaan penilaian para ulama tentang ke-mutawâtir-an mata rantai (sanad) periwayatannya.

Analisis data dalam penelitian ini menggunakan teknik analisis isi (content analysis), yakni teknik penelitian yang berusaha untuk menguraikan secara objektif, sistematis dan kuantitatif isi yang termanifestasikan dalam suatu teks. ${ }^{11}$ Teknik analisis isi mencakup prosedur pemrosesan data ilmiah yang bertujuan memberikan pengetahuan, membuka wawasan baru, menyajikan fakta dan panduan praktis pelaksanaannya. Menurut Krippendorff, analisis isi dapat dikarakterisasikan sebagai metode penelitian makna simbolik pesan-pesan. ${ }^{12}$

\section{Keharusan Periwayatan Ayat-ayat al-Qur’an Secara Mutawâtir}

Para ulama sepakat bahwa semua ayat al-Qur'an harus didasarkan pada periwayatan yang mutawâtir, sehingga terjamin validitas sumbernya. Dengan demikian keotentikannya (qath $̂ \hat{~ w u r u ̂ d ~}$ âyi al-Qur'ân) tidak terbantahkan. ${ }^{13}$ Sebagian besar ulama ushul sepakat bahwa mutawâtir merupakan syarat itsbât (penetapan),

${ }^{10}$ M. Subhana \& M. Suderajat, Dasar-Dasar Penelitian Ilmiyah, (Bandung: CV. Pustaka Setia, 2005), 77

11Lihat Hasan Sadily, Ensiklopedia, (Jakarta: Ikhtiar Baru Van Hoeve, 1980), 207.

${ }^{12}$ Klaus Krippendorff, Analisis Isi: Pengantar Teori dan Metodologi, Terj. Farid Wajdi (Jakarta: Rajawali Press, 1991), 17.

13Al-Zarkasyî, al-Burhân, Juz 2, 74. 
apakah suatu ayat dianggap sebagai bagian dari al-Qur’an atau tidak, sebagaimana pernyataan al-Suyûthî:

"Tidak ada perbedaan pendapat, bahwa semua bagian dari alQur’an harus (wajib) mutawâtir, baik dari sisi pokoknya, bagianbagiannya, tempatnya, topiknya dan urut-urutannya. Kalangan pentahqîq ahl al-sunnah juga berpendapat bahwa al-Qur`an harus diriwayatkan secara qath'î (mutawâtir). Sebab, biasanya sesuatu yang menghasilkan kepastian harus mutawâtir. AlQur’an adalah mukjizat agung yang menjadi pokok agama yang lurus (ashl al-dîn al-qawîm). Ia juga sebagai shirâth al-mustaqîm (jalan yang lurus), baik pada aspek global, maupun terperincinya. Adapun riwayat yang dituturkan secara ahâd dan tidak mutawâtir, secara qath î ia bukan merupakan bagian dari alQur’an. Sebagian besar kalangan ushûliyyîn berpendapat bahwa mutawâtir merupakan syarat penetapan apakah riwayat tersebut termasuk al-Qur`an atau tidak." ${ }^{14}$

Keharusan periwayatan mutawâtir dikarenakan al-Qur’an merupakan salah satu bagian dari pokok keimanan bagi kaum muslim. Melalui periwayatan mutawâtir, seorang mukmin tidak boleh meragukan keaslian dan kesempurnaan al-Qur`an. Apabila ada riwayat tentang bacaan al-Qur`an, namun tidak diriwayatkan dengan jalan mutawâtir, maka riwayat itu tidak boleh diyakini sebagai alQur’an. Bacaan al-Qur`an yang sampai ke tangan umat Islam, seluruhnya diriwayatkan secara mutawâtir. ${ }^{15}$ Riwayat-riwayat ahâad yang dianggap sebagai al-Qur`an, tidak boleh diyakini sebagai alQur`an. Para Sahabat sendiri tidak pernah melembagakan riwayatriwayat ahâad yang dianggap al-Qur`an ke dalam Mushhaf al-Imâm.

Istilah mutawâtir, secara bahasa, berasal dari kata al-tawâtur yang berarti berturut-turut/beruntun. Jika ada ucapan tawâtar almathar berarti "hujan turun secara beruntun."16 Dengan demikian, periwayatan mutawâtir secara harfiah berarti berulang-ulangnya sesuatu secara berturut-turut dengan suatu tenggang waktu tertentu. Secara terminologis, mutawâtir adalah sesuatu yang diriwayatkan atau diberitakan oleh sekelompok orang yang mustahil terjadi kesepakatan

14Al-Suyûthî, al-Itqân, Juz 1, 79.

15Pokja Forum Karya Ilmiah, Kilas Balik Teoritis Figh Islam, (Kediri Jawa Timur: PP. Lirboyo Kediri, 2008), 10.

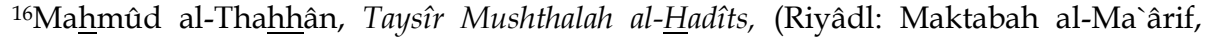
1996), 19. 
di antara mereka untuk berdusta. ${ }^{17}$ Sesuatu yang diriwayatkan secara mutawâtir ini dapat dipastikan kebenarannya. ${ }^{18}$

Berdasarkan pengertian tentang riwayat mutawâtir tersebut maka riwayat disebut mutawâtir apabila memenuhi empat syarat yaitu: (a) Diriwayatkan dari banyak perawi, namun tidak ada batasan tentang berapa jumlah mereka. Menurut pendapat yang shahîh, berjumlah 10 orang perawi; (b) Banyaknya para perawi dimaksud, ada pada setiap tingkatan sanad; (c) Mustahil secara logika mereka bersepakat dalam kedustaan; (d) Khabar yang mereka riwayatkan harus bersandarkan pada indera. ${ }^{19}$

Periwayatan secara mutawâtir bernilai qath $\hat{\imath}$ (pasti). Para perawi dalam periwayatan mutawâtir tidak perlu diselidiki tentang keadilan dan ke-dhabit-annya karena jumlah para perawinya sudah menjamin bahwa mereka tidak mungkin sepakat untuk berdusta. ${ }^{20}$ Dalam hal keotentikannya, maka Hadits mutawâtir sama dengan AlQur’an, karena keduanya merupakan sesuatu yang pasti adanya (qath'i al wurud). Itulah sebabnya, para ulama sepakat bahwa Hadits mutawâtir wajib diterima bahwa ia benar-benar Hadits.

Periwayatan yang mutawâtir terbagi menjadi tiga macam, yaitu: (1) mutawâtir lafzhî dan (2) mutawâtir ma`nawî̀, dan (3) mutawâtir

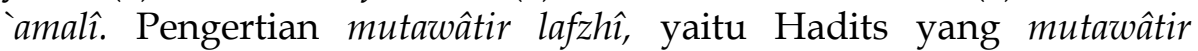
periwayatannya dalam satu lafal (teks) Hadits dan maknanya.. ${ }^{21}$ Sedangkan mutawâtir ma`nawî̀, yaitu Hadits mutawâtir yang para perawinya berbeda dalam menyusun redaksi Hadits tersebut, namun terdapat persesuaian atau kesamaan dalam maknanya. ${ }^{22}$ Lain halnya dengan mutawâtir 'amalî, yaitu "sesuatu yang diketahui dengan mudah, bahwa dia termasuk urusan agama dan telah mutawâtir antara umat Islam, bahwa Nabi mengerjakannya, menyuruhnya, atau selain dari itu. Dan pengertian ini sesuai dengan pengertian Ijmâ.'"23

\footnotetext{
17 Ibid.

18Badr al-Dîn Muhammad Bahâdir ibn Abdillah al-Zarkasyî, al-Bahr al-Muhîid fî̀ Ushûl al-Fiqh, Juz 2, (Beirut: Dâr al-Kutub al-'Ilmiyyah, 2000), 296.

19Mahmûd al-Thahhân, Taysîr Mushthalah al- $\underline{\text { Hadits, }} 20$.

20Ibid.

21Suparta, Ilmu Hadis, (Jakarta: PT. Raja Grafindo Persada, 1996), 87.

${ }^{22}$ Hadis Mutawatir dan Ahad. http://nabildaffa.blogspot.com/2012/01/makalahHadis-mutawatir-dan-ahad.html, (Diakses, 3 Desember 2012),

23Suparta, Ilmu Hadis, 90-91.
} 
Implikasi Perdebatan tentang Basmalah

\section{Perbedaan Pendapat tentang Keberadaan Basmalah dalam al- Qur'an}

Istilah basmalah merujuk pada ungkapan bismillâh al-Rahmân al-Rahîm (Dengan menyebut nama Allah Yang Maha Pemurah lagi Maha Penyayang). ${ }^{24}$ Lafal basmalah dapat dijumpai pada awal setiap surah ${ }^{25}$ dalam al-Qur’an, kecuali surah Barâ'ah [9].26 Di samping itu,

${ }^{24}$ Allah juga mengawali turunnya al-Qur`an, pada wahyu pertama, dengan memerintahkan Nabi Muhammad untuk melakukan pembacaan dan mengawali semua aktifitasnya dengan nama Allah, iqra' bismi Rabbika. Kemudian Nabi Muhammad juga menganjurkan membacanya ketika hendak memulai hal-hal yang penting, dalam sabdanya:

عن أبي هريرة قال: قال رسول الله صلى الله عليه وسلم كل أمر ذي بال لا يبدأ فيه ب $\}$ بسم الله الرحمن الرحيمج

Dari Abî Hurairah, ia berkata: Telah bersabda Rasulullah Saw: "Setiap perkara yang penting yang tidak dimulai dengan bacaan bismillâh al-Rahmân al-Rahîm, maka perkara itu terputus (keberkahannya)." (H.R. al-Hâfidz “Abd al-Qâdir al-Rahâwî). Baca Yahyâ bin Syarf al-Nawawî, al-Adzkâr al-Nawawî, Juz 1, (Beirut: Dâr al-Fikr, t.t.), 112.

${ }^{25}$ Kata surah berasal dari bahasa Arab, sûrah, secara leksikal mempunyai banyak arti, diantaranya berarti bangunan. Sûrah juga berarti kemuliaan, kebaikan, alamat, pangkal (dinding), pagar atau batas Abû al-Wafâ Ahmad 'Abd al-Âkhir, al-Mukhtâr min 'Ulûm al-Qur'ân al-Karîm, Jilid 1, (al-Mishr: al-Maktab al-Mishrâ al-Hadîts, t.t), 133. Baca juga Louis Ma'luf, al-Munjid fì al-Lugah wa al-A lâm, 362. Secara terminologis, al-Zarqânî menjelaskan pengertian surah dengan "satu kelompok mandiri yang terdiri dari ayat-ayat al-Qur’an yang mempunyai batas permulaan dan batas akhir." Baca Muhammad 'Abd al-'Azhîm al-Zarqânî, Manâhil al-'Irfân fî 'Ulûm al-Qur'ân, Jilid 1, (Beirut: Dâr al-Kitâb al-`Arabî, 1995), 285. Pendapat yang relatif sama disampaikan oleh al-Ja'barî sebagaimana dikutip oleh al-Suyûthî, menyatakan bahwa batasan disebut sebuah surah yaitu bacaan yang meliputi atas beberapa ayat yang memiliki pembukaan dan penutup, dan paling sedikitnya adalah tiga ayat. Pendapat lain menyatakan, "Surah adalah sekolompok ayat yang diberi nama dengan nama tertentu yang didasarkan pada petunjuk dari Nabi saw. Lihat al-Suyûthî, alItqân, 82. Kata surah diserap ke dalam bahasa Indonesia menjadi surat, kertas dan sebagainya yang bertulis (berbagai-bagai isi dan maksudnya). Kamus Besar Bahasa Indonesia, (Jakarta: Pusat Bahasa Departemen Pendidikan Nasional, 2003), 1108.

26Terdapat beberapa penjelasan, kenapa pada Q.S. al-Barâ'ah [9] tidak diawali dengan lafal basmalah. Al-Zarkasyî menuturkan bahwa sesuai dengan adat istiadat orang Arab, jika satu pihak hendak membatalkan perjanjian damai, maka pihak tersebut mengirimkan sebuah surat tanpa kalimat basmalah. Lantas ketika turun surah alBarâ'ah [9] atau yang juga dikenal dengan nama al-Taubah, yang membatalkan perjanjian perdamaian antara orang Islam dengan orang-orang kafir, ‘Alî membacakannya kepada mereka juga tanpa basmalah sebagaimana kebiasaan mereka. 
lafal basmalah juga disebutkan di pertengahan surah, yaitu dalam Q.S. al-Naml 27: 30, yang berbunyi:

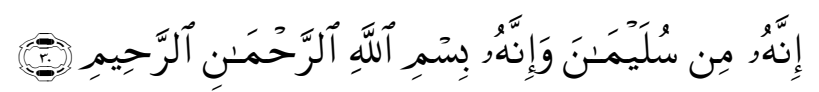

Sesungguhnya surat itu, dari SuIaiman dan Sesungguhnya (isi)nya: "Dengan menyebut nama Allah yang Maha Pemurah lagi Maha Penyayang.

Dengan demikian, lafal Basmalah dalam al-Qur`an disebutkan sebanyak 114 kali dengan merujuk pada pendapat yang paling umum diterima bahwa jumlah surah al-Qur`an sebanyak 114 surah. ${ }^{27}$ Pendapat yang berbeda diterima dari Mujâhid, bahwa surah alQur’an adalah 113 surah dengan menggabungkan surah al-Anfâl [7] dengan surah al-Barâ'ah [9]. Sedangkan Ibn Mas`ûd dalam Mushaf nya terdapat 112 surah dengan tidak memasukkan dua surah terakhir (al-mu 'âwwidzatayn). ${ }^{28}$ Sementara sebagian ulama Syi’ah menetapkan 116 surah, dengan memasukkan dua surah Qunût, yaitu surah alKhawf dan al- Hafd yang oleh ditulis oleh Ubay di kulit al-Qur`an. ${ }^{29}$ Dari susunan surah yang ada dalam al-Mushhaf disepakati bahwa surah al-Fâtihah merupakan surah pertama. Sementara surah terakhir masih diperselisihkan, sesuai dengan perbedaan tentang dasar penyusunan surah-surah al-Qur`an tersebut. ${ }^{30}$

Baca Badr al-Dîn al-Zarkasyî, al-Burhân fî 'Ulûm al-Qur'ân, Jilid 1, Cet. ke-1 (Beirut: Dâr al-Kutub al-'Ilmiyyah, 2007), 185. Sedangkan menurut 'Alî, tidak ditulisnya basmalah pada awal Surah Barâ'ah, "Karena basmalah menjamin perdamaian, sementara surah Barâ'ah diturunkan untuk memutuskan perjanjian damai. Dalam riwayat lain disebutkan, bahwa Usman ibn Affan berkata: "Surah al-Anfâl adalah bagian awal yang diturunkan dan surah Barâ'ah adalah bagian akhirnya. Keduanya memuat kisah yang mirip. Nabi saw. memisahkan keduanya tanpa ada penjelasan pada kami. Kami menduga bahwa surah Barâ'ah termasuk bagian surah al-Anfâl, kemudian kami memisahkannya tanpa basmalah". Informasi selengkapnya dapat dibaca dalam Ibid, 185-186. Baca juga al-Shâbûnî, Shafwah al-Tafâsîr, Jilid 1, 519.

27Muhammad Abû Syuhbah, al-Madkhal li Dirâsat al-Qur'ân al-Karîm, Jilid 2, (alQâhirah: Dâr al-Kutub, 1973), 276.

${ }^{28 B a c a}$ al-Suyûthî, al-Itqân, 67; dan Abû Syuhbah, al-Madkhal, Jilid 2, 288.

${ }^{29}$ Baca Ash-Shiddiqi, Sejarah dan Pengantar ilmu al-Qur'an/Tafsir, 58.

${ }^{30}$ Ada tiga pendapat yang muncul tentang dasar penyusunan surah-surah al-Qur`an, yaitu: 1), berdasarkan petunjuk Rasulullah Saw. (tawqîfî), 2) Ijtihâd para sahabat, dan 3) sebagian bersifat tawqîfi dan sebagian lagi adalah ijtihâd sahabat. Baca lebih lanjut Abû Syuhbah, al-Madkhal, Jilid 2, 293. Baca juga al-Qaththân, Mabâhits, 135-136. 
Berbicara mengenai keberadaan lafal basmalah, para ulama sepakat bahwa lafal basmalah pada Q.S. al-Naml 27:30 adalah ayat alQur'an. ${ }^{31}$ Sedangkan lafal basmalah pada awal surah masih diperselisihkan. Al-Shâbûnî menyebutkan adanya tiga pendapat ulama mengenai permasalahan ini, yaitu:

1. Basmalah merupakan satu ayat dari surah al-Fâtihah, dan juga satu ayat dari seluruh surah al-Qur`an. Pendapat ini disampaikan oleh mazhab al-Syâfi î.

2. Basmalah bukan merupakan satu ayat dari surah al-Fâtihah dan juga bukan satu ayat dari surah-surah al-Qur`an. Pendapat ini disampaikan oleh mazhab Mâlikî.

3. Basmalah merupakan satu ayat yang sempurna dari Al-Qur`an yang diturunkan sebagai pemisah antara surah-surahnya. Dan basmalah bukan merupakan satu ayat dari surah al-Fâtihah. Pendapat ini disampaikan oleh mazhab Abû Haniffah. ${ }^{32}$

Penjelasan yang relatif berbeda mengenai perbedaan pandangan para ulama tentang keberadaan lafal basmalah pada awal setiap surah disampaikan oleh Wahbah al-Zuhaylî sebagai berikut:

1. Pendapat mazhab Mâlikiyyah dan Hanafiyyah, basmalah bukanlah satu ayat dari surah al-Fâtihah dan surah-surah lainnya.

2. Pendapat Abdullah Ibn al-Mubârak, basmalah merupakan bagian ayat dari tiap surah;

3. Pendapat mazhab Syâfi iyyah dan Hanâbilah, basmalah merupakan satu ayat dari surah al-Fâtihah. ${ }^{33}$

Al-Zuhaylî juga menjelaskan bahwa sebenarnya al-Syâfi î menyampaikan dua pendapat tentang keberadaan basmalah pada awal surah selain surah al-Fâtihah. Namun menurut riwayat yang

31Muhammad 'Alî al-Shâbûnî, Tafsîr Âyâtil Ahkâm min al-Qur'ân, Juz 1, Cet. ke-1 (Beirut: Dâr al-Qur'ân al-Karîm, 2004), hlm. 33-34. Baca juga Muhammad Alî al-Says, Tafsîr Âyât al-Ahkâm, Vol. 1, (T.tp: Kulliyyat al-Syarâ‘ah al-Islâmiyyah, t.t.), 3.

32Informasi selengkapnya termasuk dalil-dali yang digunakan oleh masing-masing mazhab dapat dibaca pada al-Shâbûnî, Tafsîr, Juz 1, 33 - 37. Baca juga Departemen Agama RI., Al-Qurian dan Tafsirnya, Jilid I, edisi yang disempurnakan, (Jakarta: Lentera Abadi, 2010), 11-12.

33Informasi selengkapnya dapat dilihat dalam Wahbah al-Zuhaylî, at-Tafsîr al-Munîr fî al-`Aqîdah wa al-Syarî̀ah wa al-Manhaj, Juz. 1, (Beirut: Dâr al-Fikr al-Mu âshir, 1998), 46-48. 
paling shahîh, al-Syâfi î̀ lebih memilih pendapat yang menyatakan bahwa basmalah pada setiap awal dalam al-Qur`an termasuk salah satu ayat dari surah tersebut. Sedangkan mazhab Mâlik dan mazhab Abû Hanîfah sama-sama menganggap basmalah bukan bagian dari surah al-Fâtihah dan surah-surah lainnya, namun ada perbedaan di antara keduanya. Mâlikiyyah menyatakan basmalah memang bukan bagian dari al-Qur`an, sedangkan Hanafiyyah menyatakan bagian dari al-Qur`an, tapi tidak berada dalam surah, melainkan sebagai pemisah antar surah. ${ }^{34}$

\section{Keberadaan Basmalah Ditinjau dari Sumber Periwayatannya}

Kajian mengenai keberadaan basmalah, khususnya yang terdapat pada awal surah al-Fâtihah, menjadi perhatian banyak ulama, karena dikaitkan dengan keabsahan shalat, sebagaimana sabda Nabi Muhammad Saw.:

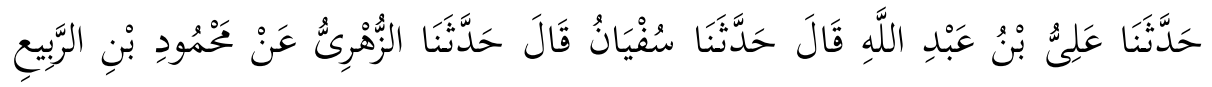

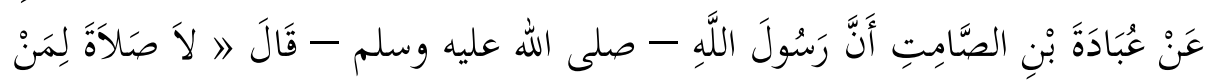

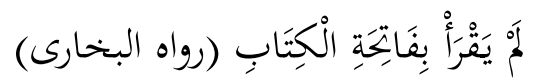

Telah menceritakan kepada kami Ali bin Abdullah, ia berkata: telah bercerita kepada kami Sufyân, ia berkata: telah bercerita kepada kami al-Zuhrî dari Mahmûd bin alRabî' dari 'ubâdah bin al-Shâmit bahwa sesungguhnya Rasulullah Saw. bersabda: "Tidak sah shalat bagi orang yang tidak membaca Fâtihat al-Kitâb (surah alFâtihah)." (HR. al-Bukhârî). ${ }^{35}$

Sesungguhnya para ulama sepakat bahwa jumlah ayat dalam surah al-Fâtihah [1] disepakati sebanyak tujuh ayat. Kesepakatan ini didasarkan pada salah satu nama dari surah ini, yaitu al-Sab`u alMatsânî (tujuh ayat yang berulang), ${ }^{36}$ sebagaimana dinyatakan oleh

34Ibid.

35Muhammad bin Isma îl Abû `Abdillah al-Bukhârî, al-Jâmi al-Shahîh al-Mukhtashar, Ed. Muhammad Dîb al-Bighâ', Vol. 1 (Beirut: Dâr Ibn Katsîr, 1987), 263.

36Penamaan surah al-Fatihah dengan al-Sab' al-Matsân̂̂ (tujuh ayat yang berulang) karena seringnya dibaca ketika shalat maupun di luar shalat. Bagi ulama yang berpendapat bahwa Basmalah merupakan ayat pertama, maka ayat ke 7 dimulai dari lafal shirâth al-ladzîna sampai akhir ayat. Sedangkan bagi yang berpendapat bahwa Basmalah merupakan ayat tersendiri atau tidak terhitung sebagai ayat al-Qur`an, maka ayat ke 7 dari surah al-Fâtihah dimulai dari lafal gayr al-mawdhûbi ‘alayhim 
Implikasi Perdebatan tentang Basmalah

Allah bahwa Dia telah memberikan kepada manusia tujuh ayat yang dibaca berulang-ulang dan Al Quran yang agung. ${ }^{37}$

Hal ini juga disebutkan dalam Hadits yang diriwayatkan oleh Imam al-Tirmidzî dari Abu Hurayrah, yang dikutip oleh Ibn Katsîr, bahwa Rasulullah bersabda:

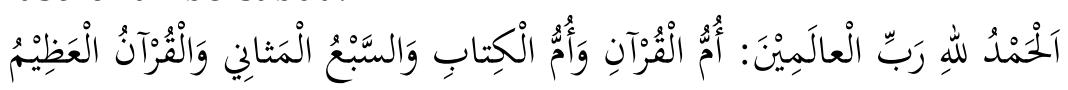

"Al-hamd lillâh Rabb al-'alamîn (al-Fâtihah) adalah induk al-Qur'an, induk al-kitab, tujuh ayat yang berulang, dan al-Qur'ân al-Azhîm."38

Dalam penjelasannya, al-Syafi î menyatakan bahwa "Yang dimaksud dengan al-Qur`an yang agung itu adalah Umm al-Qur'ân, ayat pertamanya adalah lafal bism Allâh al-Rahımân al-Rahîm."39 Pendapat al-Syafi î tersebut juga didasarkan pada berbagai riwayat lainnya yang diterimanya, semisal riwayat yang diterima dari Sa `îd bin Jubair. ${ }^{40}$

sampai akhir ayat. Surah ini juga disebut Umm al-Kitâb dan al-Qur'ân al-'Azhîm. Penamaan dengan Umm al-Kitâb (induk Alkitab), karena makna-makna al-Qur`an semuanya kembali kepada kandungan surah al-Fâtihah ini. Sedangkan Surah alFâtihah juga disebut al-Qur'ân al-Azhîm (bacaan yang agung) karena memuat pesanpesan penting yang akan dirinci pada surah-surah berikutnya. Baca Âdam Bombâ, Asmâ' al-Qur'ân al-Karîm, Cet. ke-1 (Dabî: Markaz Jama`atul Mâjid li al-Tsaqâfah wa al-Turâts, 2009), 51-68. Baca Abû al-Fidâ' Ismâ'îl ibn ' 'Umar ibn Katsîr al-Dimasyqi, Tafsîr al-Qur'ân al-Azhîm, Jilid 1, (Jîzat: Mu'assasah Qurthubah, t.t.), 151.

${ }^{37}$ Al-Qur'an, Surat al- $\underline{\text { Hijr }}$ 15: 87

38Ibn Katsîr juga menyebutkan beberapa nama lainnya, semisal al- $\underline{H} a m d u$ karena dimulai dengan lafal al-hamd lillâh Rabb al-'alamîn, al-Shalâh karena ia menjadi salah satu syarat sahnya shalat, al-Syifâ (kesembuhan), al-Ruqyah, Asâs al-Qur'ân (pokokpokok al-Quran), al-Waqiyah (yang menjaga), al-Kâfiyah (yang mencukupi), dan alKunz (perbendaharaan). Ibid., 151-153.

${ }^{39}$ Abû Abdillah Muhammad bin Idrîs al-Syâfi î, Ahkâm al-Qur'ân, Juz 1, (Beirut: Dâr al-Kutub al-'Ilmiyyah, 1400 H.), 62-63.

40Baca al-Syâfi î̀, Ahkâm al-Qur'ân, Juz 1, 62-63, dengan redaksi selengkapnya adalah sebagai berikut:

أنا أبو زكريا بن أبي إسحاق في آخرين قالوا أنا أبو العباس محمد بن يعقوب أنا الربيع أنا الشافعي أنا عبد المجيد عن

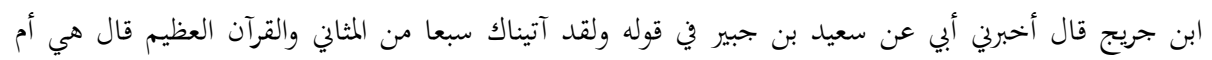

القرآن قال أبي وقرأها علي سعيد بن جبير حتى ختمها ثم قال بسم الله الرحمن الرحيم الآية السابعة قال سعيد

وقرأها علي ابن عباس كما قرأقها عليك ثم قال بسم الله الرحمن الرحيم الآية السابعة قال ابن عباس فذخرها الله

لكم فما أخرجها لأحد قبلكم.قال الشافعي في رواية حرملة عنه وكان ابن عباس يفعله يعني يفتتح القراءة ببسم الله 
Lafal basmalah pada awal surah al-Fâtihah, dan surah-surah lainnya kecuali surah al-Barâ'ah [9], menurut mazhab al-Syâfi î̀ dan juga madzhab Hanbalî merupakan ayat pertama dari surah-surah tersebut. Pandangan ini sejalan pendapat dari sebagian shahabat, di antaranya adalah Ibn 'Abbâs, Ibn 'Umar, Ibn al-Zubayr, Abû Hurayrah, 'Alî ibn Abî Thâlib, 'Athâ', Thâwus, Sa'îd ibn Jubayr, Makhul, al-Zuhrî, 'Abdullah ibn al-Mubârak, Ahmad ibn Hanbal (dalam salah satu riwayat), Ishâq ibn Rahawayh, dan Abû ‘Ubayd alQasim ibn Salam. ${ }^{41}$

Di samping itu, berbagai sumber periwayatan lainnya juga mendukung pandangan ini, semisal:

a. Hadits yang diriwayatkan oleh al-Bayhaqî dari Abû Hurayrah,42 berkata bahwa Rasulullah Saw bersabda "Jika kalian membaca alhamdulillâhi, maka bacalah bismillâh al-Rahmân al-Rahîm. Sesungguhnya ia adalah Umm al-Qur'ân, Umm al-Kitâb, Tujuh ayat yang berulang. Dan lafal bismillâh al-Rahmân al-Rahîm adalah salah satu ayatnya"

b. Dalam Hadits yang diriwayatkan dari Anas r.a, ketika ia ditanya tentang bacaan Rasulullah (di dalam shalat), ia menjelaskan bahwa "Bacaannya panjang-panjang... Kemudian ia membaca: bismillâh al-Rahmân al-Rahîm, alhamd lillâhi rabb al'âlamîn, al-Rahmân al-Rahîm, mâliki yawm al- dîn...'. (Hadits ini

$$
\begin{aligned}
& \text { الرمن الرحيم ويقول انتزع الشيطان منهم خير آية في القرآن وكان يقول كان النبي لا يعرف ختم السورة حتى تنزل } \\
& \text { بسم الله الرمن الرحيم. }
\end{aligned}
$$


dikeluarkan oleh al-Bukhari dan al-Dâraquthnî. Dalam komentarnya, al-Dâraquthnî berkata bahwa sanadnya shahîh).43

c. Hadits dari Anas r.a, ia berkata: Suatu hari Rasulullah berada di hadapan kami, dan ia menunduk, kemudian beliau mengangkat kepala sambil tersenyum. Kami bertanya, 'Apa yang membuatmu tertawa wahai Rasulullah?', beliau menjawab, 'Baru saja turun surah kepadaku', kemudian beliau membaca, 'bismillâh al-Rahmân al-Rahîm, innâ a'thaynâka alkautsar, fa shalli li rabbika wanhar, inna syâni'aka huwa al-abtar'. (HR. Muslim, al-Nasâ'i, al-Tirmidzi, dan Ibn Majah. Imam al-

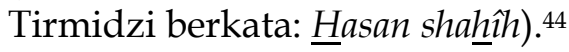

d. Hadits yang diriwayatkan oleh al-Nasâ'î, Ibn Khuzaimah, dan Ibn Hibbân, al-Hâkim dari Abû Hurayrah bahwa ia shalat kemudian ia mengeraskan bacaan basmalah-nya. ${ }^{45}$

e. Hadits yang diriwayatkan oleh Abû Dâwûd dan al-Turmudzî dari Ibn Abbâs:

${ }^{43}$ Al-Sâyis, Tafsîr Âyât al-Ahkkâm, Vol. 1, 4. Redaksi selengkapnya adalah sebagai berikut:

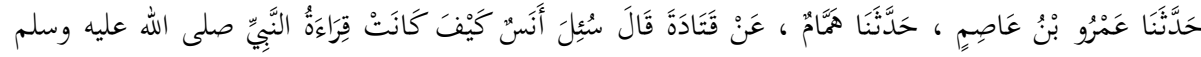

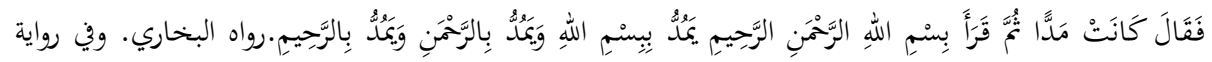

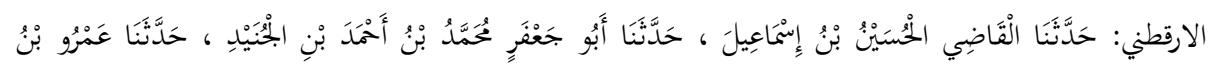

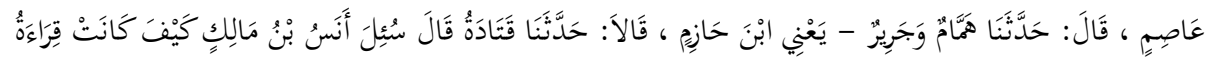

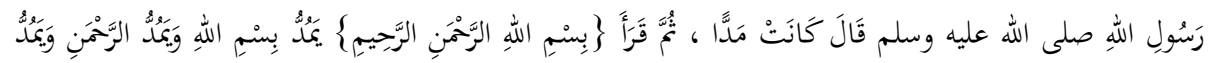

${ }^{44} \mathrm{Ahmad}$ bin Syùayb Abu Abd al-Rahman al-Nasâ'î, al-Mujtabâ min al-Sunan, ed. Abd al-Fattâh Abû Ghuddah, Vol. 2, (Halb: Maktab al-Mathbû'ât al-Islâmiyyah, 1986), 133. Redaksi Hadits selengkapnya dalam riwayat al-Nasâ'î adalah:

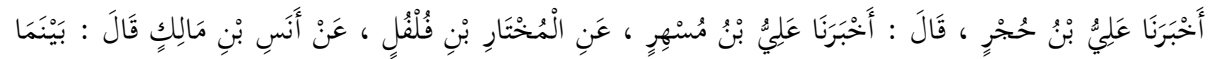

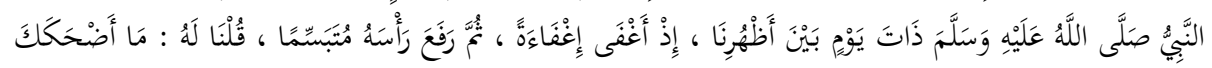

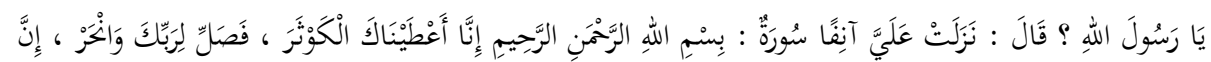

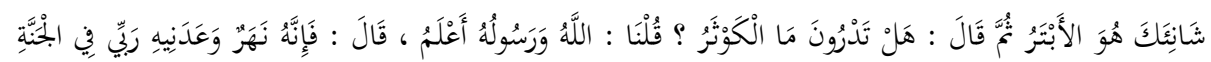

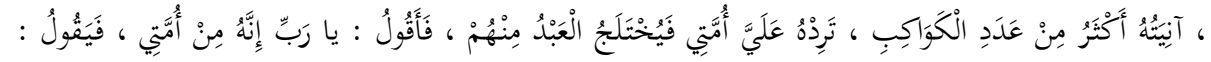

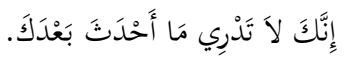

45Ibn Katsîr, Tafsîr al-Qur'ân al-Azhîm, Jilid 1, 179-180. 
"Sesungguhnya Rasulullah Saw membuka bacaan shalatnya dengan bismillâh al-Rahmân al-Rahîm" Al-Tirmidzi berkata, "Penyandaran sanadnya tidaklah demikian." 46

f. Hadits yang diriwayatkan oleh al-Hâkim dalam Kitab Mustadraknya, dari Ibn Abbâs yang menjelaskan bahwa "Rasulullah Saw menyaringkan (bacaan dalam shalat) lafal bismillâh al-Rahmân al-Rahîm." 47

g. Penjelasan senada dengan Hadits tersebut disampaikan oleh Umm Salamah yang diriwayatkan dalam Kitab Musnad Ahmad, Sunan Abî Dâwî̀d, Shahîh Ibn Khuzaymah, dan Kitab Mustadrak al-Hâkim, bahwa "Rasulullah Saw memotong bacaannya (ketika membaca surah al-Fâtihah) dengan bacaan: bismillâh al-Rahmân al-Rahîm, alhamd lillâhi rabb al-'âlamîn, alRahmân al-Rahîm, mâliki yawm al-dîn...'. Al-Dâruquthnî menilai bahwa "Penyandaran sanadnya shahîh"48

Dari sudut pandang yang berbeda, mazhab Abû Hanifah menyatakan bahwa penulisan basmalah dalam al-Mushhaf menunjukkan bahwa basmalah adalah bagian dari al-Qur`an, namun tidak menunjukkan bahwa ia adalah ayat dari setiap surah. ${ }^{49}$ Sedangkan Hadits-Hadits yang menunjukkan tidak dibacanya basmalah secara jahr (nyaring) dalam shalat saat membaca al-Fâtihah menunjukkan bahwa ia bukanlah bagian dari al-Fâtihah. Meski demikian, mazhab ini tetap membaca basmalah sebelum al-Fâtihah secara pelan-pelan (sirr) pada setiap rakaat. Dalam penilaian Muhammad 'Ali al-Shabuni, bahwa pandangan ini merupakan pandangan yang menengahi dua pandangan yang kontradiktif, yakni pendapat madzhab al-Syâfi î̀ dan mazhab Mâlik. ${ }^{50}$

\footnotetext{
46Ibid., 180.

47Ibid., 180-181dengan redaksi sebagai berikut: كان رسول الله صلى الله عليه وسلم يجهر ببسم الله الرمن الرحيم، ثم قال: صحيح

48Ibid., hlm. 181, dengan redaksi sebagai berikut:

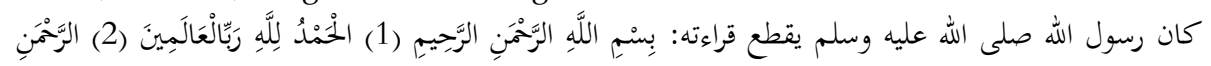

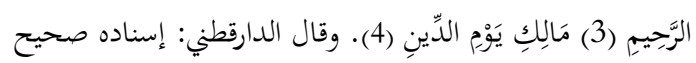

${ }^{49}$ Ibid., 36.

50Baca al-Shâbûnî, Tafsîr Âyâtil Ahkâm, Jilid 1, 37-38.
} 
Pendapat Abû Hanifah tersebut didasarkan pada beberapa sumber periwayatan, semisal:

a. Hadits yang diriwayatkan dari Anas bin Mâlik, ia berkata: "Saya Shalat bersama Rasulullah, Abu Bakar, 'Umar, dan Ustman Radhiya Allahu 'anhum, dan saya tidak mendengar satupun dari mereka membaca bismillâh al-Rahmân al-Rahîm."51

b. Hadits yang diriwayatkan oleh Abû Dâwûd dengan sanad yang shahîh dari Ibn Abbas, berkata bahwa "Rasulullah dulu tidak mengetahui pemisah surah hingga turun kepadanya bismillâh al-Rahmân al-Rahîm"52

c. Riwayat yang dikeluarkan oleh al-Hâkim dan Abû Dâwûd dari Ibn 'Iyâsy dengan sanad yang shahîh, bahwa dari para shahabat pernah berkata, "Dulu kami tidak mengetahui akhir setiap surah, hingga turun bismillâh al-Rahmân al-Rahîm". 53

d. Pendapat ini juga dikuatkan dengan kenyataan bahwa surah al-Mulk terdiri dari 30 ayat, berdasarkan Hadits Nabi Saw. Para ahli qirâ'at dan lainnya juga sepakat bahwa surah al-Mulk terdiri dari 30 ayat, jika basmalah tidak dimasukkan. Jika basmalah dimasukkan, maka menjadi 31 ayat, dan ini menyelisihi Hadits Nabi Saw. Para ahli qirâ'at dan ahli fiqih dari berbagai penjuru negeri sepakat bahwa surah al-Kautsar terdiri dari 3 ayat, dan surah al-Ikhlash terdiri dari 4 ayat. Jika ditambah basmalah, maka jumlahnya akan lebih dari itu, dan ini menyelisihi kesepakatan ulama qirâ'at dan fiqh. ${ }^{54}$

Sementara menurut pandangan mazhab Mâlikî, basmalah bukan merupakan ayat dalam al-Qur`an, bukan bagian al-Fâtihah, dan juga bukan bagian dari surah yang lain. ${ }^{55}$ Berbagai sumber

51Ibid., 181-182, dengan redaksi sebagai berikut:

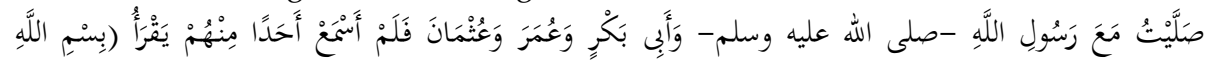

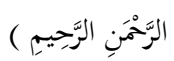

${ }^{52 A b u ̂ ~ D a ̂ w u ̂ d ~ b i n ~ S u l a i m a ̂ n ~ b i n ~ a l-A s y ` a t s ~ a l-S i j i s t a ̂ n i ̂, ~ S u n a n ~ A b i ̂ ~ D a ̂ w u ̂ d, ~ V o l . ~ 1, ~}$ (Beirut: Dâr al-Kitâb al-'Arabî, t.t.), 288. Baca juga al-Shâbûnî, Tafsîr Âyâtil Ahkkâm, Jilid 1,37, dengan redaksi sebagai berikut:

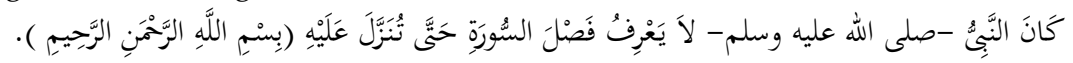

53Ibid.

54 Ibid.

55Ibid., 4. 
periwayatan yang dijadikan dalil untuk mendukung pendapatnya adalah sebagai berikut:

a. Dalam riwayat Muslim dari 'Āisyah yang menceritakan adanya Hadits bahwa Rasulullah Saw. membuka shalatnya dengan takbir, dan bacaannya dengan alhamd lillâhi rabb al'âlamîn. Hadits ini menunjukkan bahwa Basmalah bukanlah satu ayat dari surah al-Fâtihah. Seandainya ia adalah satu ayat dari surah al-Fâtihah, maka tentu wajib membacanya beserta surah al-Fâtihah di dalam shalat. 56

b. Dalam riwayat yang lain dijelaskan, bahwa Anas r.a berkata:

"Aku shalat di belakang Nabi, Abu Bakr, “Umar, dan 'Utsmân. Mereka semuanya membuka bacaan shalatnya dengan al-Hamdu lillâhi rabb al-'âlamîn." (HR. al-Bukhari dan Muslim). Dalam redaksi Muslim, dikatakan: "Mereka tidak menyebut bismillâh al-Rahmân al-Rahîm, tidak di awal bacaan, tidak juga di akhir." 57

56Ibid. Redaksi Hadits selengkapnya adalah sebagai berikut:

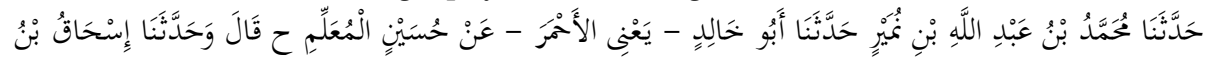

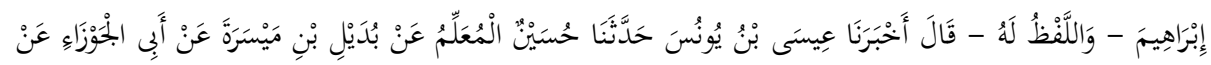

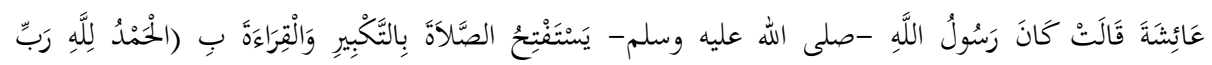

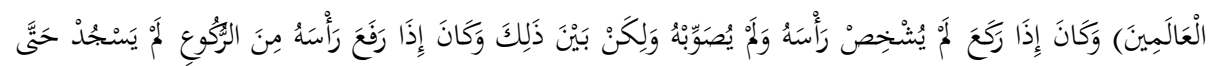

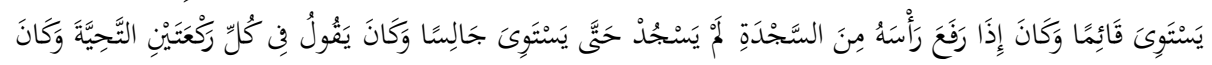

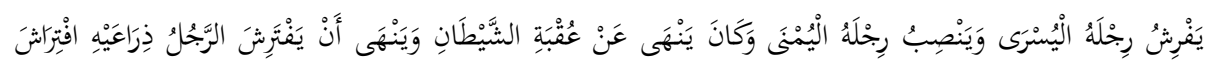

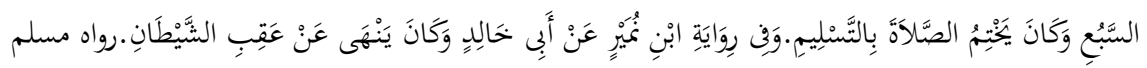
57 Sedangkan redaksi Hadits selengkapnya adalah sebagai berikut:

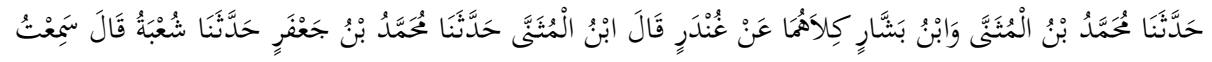

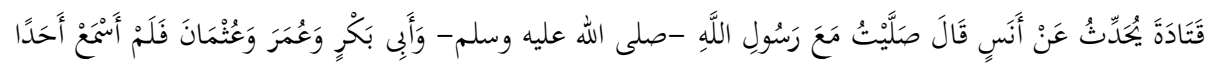

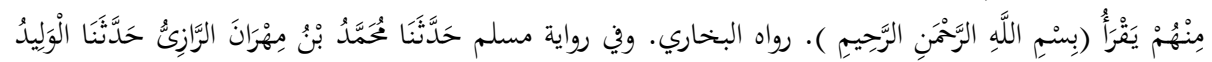

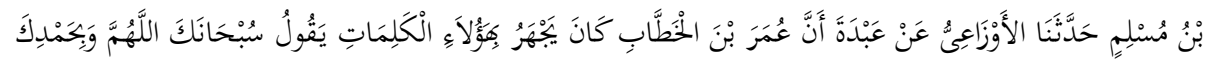

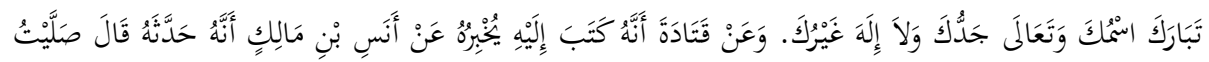

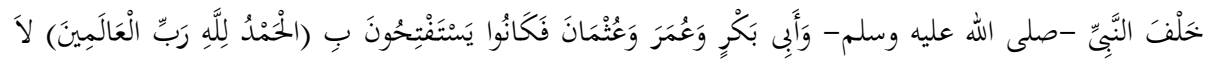

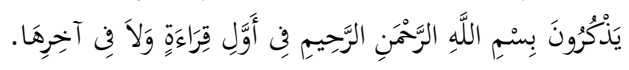


c. Dalam sebuah Hadits Qudsi, Allah berfirman: "Aku bagi shalat antara Aku dan hamba-Ku dua bagian, dan bagi hamba$\mathrm{Ku}$ apa yang ia minta ..." (HR. Muslim dari Abu Hurayrah). Kemudian disebutkan ayat-ayat al-Fâtihah, dan tidak disebutkan basmalah padanya. Pendukung pendapat ini menyatakan, firman Allah, 'Aku bagi shalat' maksudnya adalah al-Fâtihah. Surah ini dinamakan 'shalat' karena shalat tak sah tanpanya. Seandainya basmalah salah satu ayat dari alFâtihah, tentu ia disebutkan dalam Hadits Qudsi ini.

d. Dalam Hadits riwayat Abû Dâwûd dari Anas bahwa Nabi Saw., Abu Bakr, “Umar, dan 'Utsmân. Mereka semuanya membuka bacaan shalatnya dengan bacaan al-hamd lillâhi rabb al-'âlamîn"58 Hadits ini diriwayatkan dari Muslim bin Ibrahim, Hisyâm, dari Qatâdah dari Anas bin Malik dengan keseluruhan perawi dalam Hadits ini adalah tsiqah yang secara langsung menyebutkan bacaan al-hamd lillâh.

e. Hadits riwayat at-Tirmidzi dari ÂAnas ia berkata: Nabi, Abu Bakr, “Umar, dan 'Utsmân. Mereka semuanya membuka bacaan shalatnya dengan bacaan al-hamd lillâhi rabb al'âlamîn." 59

f. Hadits riwayat Ibn Majah dari Ânas ia berkata: Nabi Saw., Abu Bakr, “Umar, dan 'Utsmân. Mereka semuanya membuka bacaan shalatnya dengan bacaan al-hamdu lillâhi rabb al"âlamîn." 60

\footnotetext{
58Sunan Abî Dâwûd, Juz 2, 435. Redaksi selengkapnya adalah sebagai berikut:

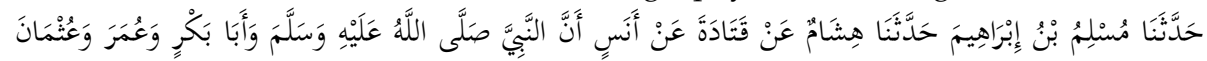

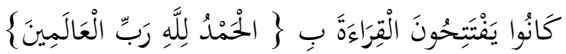
${ }^{59}$ Sunan al-Tirmidzî, Juz 1, 416. Redaksi selengkapnya adalah sebagai berikut:

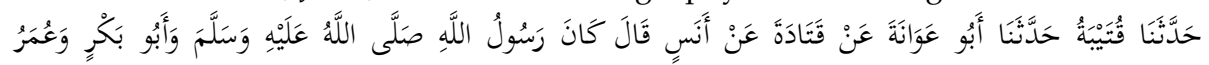

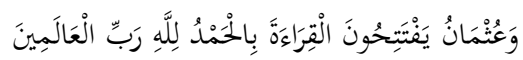
60Sunan Ibn Mâjah, Juz 3, 41. Redaksi selengkapnya adalah sebagai berikut:

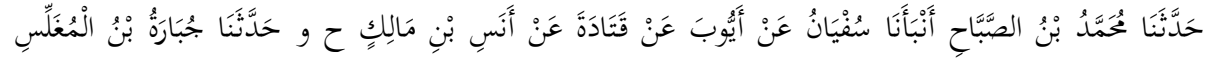

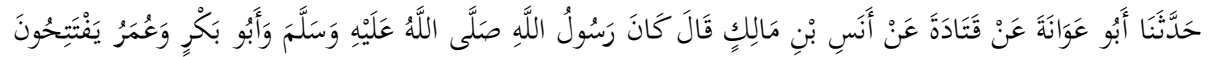

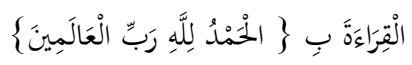




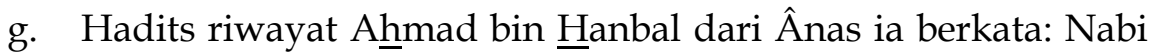
Saw., Abu Bakr, 'Umar, dan 'Utsmân. Mereka semuanya membuka bacaan shalatnya dengan bacaan al-hamdu lillâhi rabb al-'âlamîn." 61

h. Hadits riwayat al-Darimi dari Ânas berkata: Nabi, Abu Bakr, "Umar, dan 'Utsmân. Mereka semuanya membuka bacaan shalatnya dengan bacaan al-hamd lillâhi rabb al-'âlamîn." 62

Di samping itu, menyikapi pencantuman lafal Basmalah dalam Al-Qur`an, madzhab ini menanggapinya sebagai berikut:

a. Seandainya basmalah bagian dari al-Fâtihah, maka terjadi pengulangan pada frase 'al-rahmân al-Rahîm' di surah tersebut. Pengulangan seperti ini merupakan cela atau cacat dari sisi kefasihan bahasa, dan tidak layak terdapat pada Al-Qur`an. ${ }^{63}$

b. Tentang penulisan lafal basmalah di awal tiap surah, sebagaimana disampaikan oleh al-Qurthubî dan Ibn al-'Arabî adalah untuk tabarruk (meraih berkah), mengikuti perintah Allah dan Rasul-Nya untuk menulisnya, serta ia memang diminta diletakkan di awal setiap perkara. Namun hal tersebut bukan berarti bahwa lafal basmalah yang terdapat pada awal surah merupakan bagian dari al-Qur`an. Meskipun penulisannya di awal setiap surah diriwayatkan secara mutawâtir, namun keberadaannya dalam al-Mushhaf sebagai bagian dari ayat Al-Qur`an tidaklah mutawâtir. ${ }^{64}$

\section{Pertimbangan Kemutawatiran Pencantuman Lafazh Basmalah}

Sesungguhnya para ulama sama-sama mempertimbangkan kemutawatiran sumber periwayatan dalam menentukan sah atau

61Musnad Ahmad, Juz 24, 99. Redaksi selengkapnya adalah sebagai berikut:

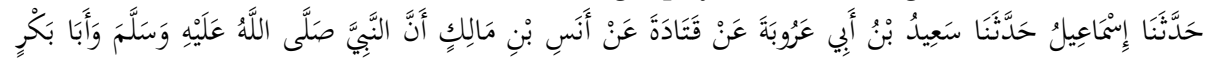

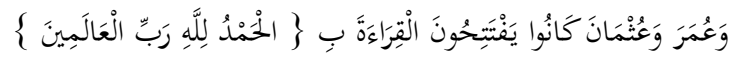

62Sunan al-Dârimî, Juz 3. 487. Redaksi selengkapnya adalah sebagai berikut:

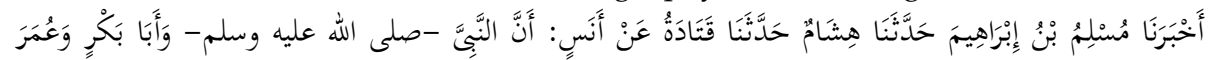

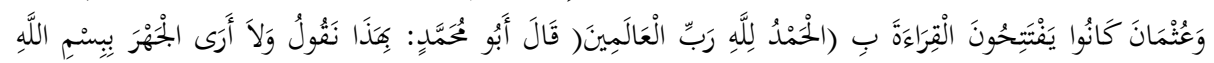

${ }^{63}$ Al-Shâbûnî, Tafsîr Âyâtil Ahkâm, Jilid 1, 36. 64Ibid. 
tidaknya sebuah ayat al-Qur`an, termasuk lafal basmalah. Namun menilik pada argumentasi sumber periwayatan di atas, baik yang menyatakan bahwa lafal basmalah sebagai ayat al-Qur`an atau bukan, menunjukkan bahwa Hadits-Hadits yang dijadikan sebagai pijakan tidak mencapai derajat mutawâtir. Keberadaan dua dalil yang bertentangan ini sama-sama bernilai ahâd.

Mazhab Mâlikî bersikukuh bahwa riwayat yang berkaitan dengan keberadaan basmalah tidak dapat digunakan untuk menetapkannya sebagai ayat al-Qur`an, meskipun riwayat yang diajukannya untuk menafikannya juga tidak bernilai mutawâtir. Kukuhnya pandangan demikian dinyatakan oleh al-Qurthubî sebagaimana yang dikutip oleh al-Zuhaylî, bahwa:

Sesungguhnya Al-Qur'an tidak dapat ditetapkan dengan menggunakan berita-berita yang bernilai ahâd. Dan hanyasanya metode penetapan AlQur'an melalui riwayat mutawâtir yang menjamin adanya kepastian yang tidak diperselisihkan lagi keberadaannya dalam Al-Qur`an. Akan tetapi masalah ini belum terang benderang, karena sesungguhnya bukanlah suatu kelaziman menetapkan kemutawatiran setiap ayat AlQur'an .65

Sesungguhnya pandangan al-Qurthubî tersebut juga disepakati oleh para ulama. Masih terjadinya perbedaan pendapat mengenai penetapan basmalah, menurut penulis, terletak pada perbedaan pilihan tentang bentuk ke-mutawâtir-annya; apakah harus (1) mutawâtir lafzhî, (2) mutawâtir mànawî, atau cukup dengan (3) mutawâtir 'amalî syarat mutawâtir itu.

Dalam pandangan al-Qurthûbî sendiri, sesungguhnya bukanlah suatu kelaziman menetapkan kemutawatiran setiap ayat alQur`an secara lafzhî (mutawâtir lafzhî). Pandangan demikian masih membuka runag penetapan ayat al-Qur`an dicukupkan pada pada mutawâtir ma'nawî̀ atau mutawâtir 'amalî. Penetapan ayat-ayat alQur`an secara mutawâtir 'amalî dapat diketahui berdasarkan sejarah pengumpulan al-Qur'an (jam' al-Qur'ân). Fakta kesejarahan menegaskan secara akademik bahwa kitab suci al-Qur`an yang sampai kepada umat Islam sekarang ini benar-benar otentik dan valid sebagaimana yang diturunkan Allah kepada Nabi Muhammad, baik bacaan maupun tulisannya tanpa mengalami penambahan atau pengurangan satu ayat, bahkan satu huruf pun.

65al-Zuhaylî, al-Tafsîr al-Munîr, Juz 1, 47. 
Sebagaimana diketahui, dalam konteks sejarah awal kaum muslimin, teks al-Qur`an yang berupa mushaf seperti yang dapat dilihat sekarang ini adalah ayat-ayat yang terpisah dan berserakan. Ayat-ayat yang turun selama masa kerasulan Muhammad saw. yang antara satu atau beberapa ayat dengan ayat yang lain diselingi beberapa waktu - tidaklah segera dikodifikasikan pada masa itu. Tetapi, atas perintah Nabi, di samping menyuruh menghafalkannya kepada para sahabat, ayat-ayat tersebut ditulis di atas pelepahpelepah kurma, batu-batu dan tulang-tulang unta66. Para sahabat pun senantiasa menyodorkan hafalan maupun tulisan al-Qur`an kepada Rasulullah. Selain al-Qur`an, yakni Hadits atau pelajaran yang diperoleh dari Nabi Muhammad, para sahabat dilarang untuk menulisnya, dengan tujuan supaya al-Qur'an itu terpelihara keasliannya, dan tidak dikhawatirkan bercampur dengan yang lain, meskipun yang didengar itu juga berasal dari Nabi. ${ }^{67}$

Pada masa Khalifah Abu Bakr, terjadi peperangan menumpas Musaylamah al-Kadzdzâb yang mengaku dirinya sebagai nabi. Peperangan tersebut menyebabkan gugurnya sejumlah huffâzh al-Qur'ân (para penghafal al-Qur`an) di kalangan para sahabat, kurang lebih tujuh puluh orang sahabat, di antaranya Zayd ibn alKhaththâb.68 "Umar ibn al-Khaththâb khawatir melihat kenyataan itu, lalu ia mengusulkan kepada Khalifah Abû Bakr (11-13 H./632-634 M.) untuk mengumpulkan dan membukukan al-Qur`an. Awalnya Khalifah Abû Bakr menolak usulan tersebut, namun setelah mempertimbangkan urgensinya, maka ia pun memerintahkan Zayd ibn Tsâbit untuk menghimpun dan menulis ayat-ayat al-Qur’an dalam lembaran-lembaran tulisan yang lebih rapi. ${ }^{69}$

Ketika penulisan al-Qur`an sudah selesai dilakukan, Khalifah Abu Bakr meminta kepada para sahabatnya agar ia diberi nama. Sebagian sahabat mengajukan usul agar shuhuf-shuhuf itu diberi nama "Injil". Sebagian sahabat yang lain mengajukan nama "al-Sifr". Tetapi para sahabat banyak yang tidak setuju karena nama itu adalah nama kitab orang Yahudi. Ibn Mas'ûd berkata: "Aku melihat di Habsyah

66Al-Shâbûnî, at-Tibyân, 53

${ }^{67} \mathrm{Al}-\mathrm{Q} a t h t h a ̂ n$, Mabâhits, 119.

68Ibid., 120. Baca juga al-Shâbûnî, at-Tibyân, 54, dan Ahmad Syadali dan Ahmad Rofi'i, Ulumul Qur'an, (Bandung: CV Pustaka Setia, 1997), I: 72.

${ }^{69}$ Baca lebih lanjut al-Qaththân, Mabâhits, 121. 
ada suatu kitab yang mereka namakan al-Mush haf, maka berilah nama kitab itu dengan al-Mushhaf.70 Kemudian lembaran-lembaran tulisan al-Qur`an tersebut diberi nama dengan al-Mushhaf.71 Dengan demikian dapat dikatakan bahwa penamaan al-Mushhaf dikukuhkan secara resmi pada masa Khalifah Abu Bakr.

Kemudian pembukuan Al-Qur`an dilakukan kembali pada masa Khalifah Usman ibn Affan (23-35 H./644-656 M.) yang dilatarbelakangi adanya perselisihan bacaan Al-Qur’an, sebagaimana yang diinformasikan oleh al-Qaththân:

Penyebaran Islam bertambah luas dan para qurrâ' pun tersebar di pelbagai wilayah, dan penduduk di setiap wilayah itu mempelajari qirâ'ât (bacaan), dan penduduk di setiap wilayah itu mempelajari qirâ'ât dari qâri' yang dikirim kepada mereka. Cara-cara pembacaan alQur'an yang mereka bawakan berbeda-beda sejalan dengan perbedaan huruf (dialek cara membaca al-Qur'an, pen.) yang dengannya alQur'an diturunkan. Apabila mereka berkumpul di suatu pertemuan atau di suatu medan peperangan, sebagian dari mereka merasa heran akan adanya perbedaan qirâ'ât ini. Terkadang sebagian dari mereka merasa puas karena mengetahui bahwa perbedaan-perbedaan itu semuanya disandarkan kepada Rasulullah saw. Tetapi keadaan demikian bukan berarti tidak akan menyusupkan keraguan kepada generasi baru yang tidak melihat Rasulullah saw., sehingga terjadilah pembicaraan tentang bacaan mana yang baku dan mana yang lebih baku. Dan pada gilirannya akan menimbulkan saling pertentangan bila terus tersiar, bahkan akan menimbulkan permusuhan dan perbuatan dosa. Fitnah yang demikian ini harus segera diselesaikan. ${ }^{72}$

Dalam sejarah pembukuan al-Qur’an juga diketahui bahwa sebelum tim penulis melaksanakan tugas penyalinan Mushhaf, Khalifah Utsmân menetapkan beberapa kebijakan yang harus dijadikan landasan kerja mereka sebagai berikut:

70Badr al-Dîn al-Zarkasyî, al-Burhân fî 'Ulûm al-Qur'ân, Cet. ke-1, (Beirût: Dâr al-Kutub al-'Ilmiyyah, 2007), I: 199. Lihat juga al-Suyûthî, al-Itqân fí 'Ulûm al-Qur'ân, 82.

71Baca Ibid. Baca juga al-Zuhaylî, at-Tafsîr al-Munîr, Jilid 1, 14., dan al-Suyûthî, alItqân, Jilid 1, 82.

72Al-Qaththân, Mabâhits, 123. Alasan pengumpulan al-Qur`an pada masa Khalifah Abu Bakr karena kekuatiran ayat-ayat al-Qur`an akan hilang, sebab pada waktu itu al-Qur'an belum terkumpul dalam satu media. Sedangkan pada masa Khalifah Utsmân adalah untuk menyamakan bacaan, karena timbulnya perbedaan dan perselisihan mengenai bacaannya, dengan menyalin shuhuf-shuhuf itu ke dalam Mushaf yang berurutan surahnya. Baca al-Suyûthî, al-Itqân, 93. 
a. Menjadikan Mushhaf Abi Bakr sebagai sumber primer dalam penyalinan Mushhaf.

b. Yang ditulis hendaknya ayat-ayat yang benar-benar diyakini sebagai ayat-ayat al-Qur`an (bukan tafsirannya), diketahui secara pasti seperti yang dipresentasikan oleh Rasulullah pada akhir hayatnya kepada Jibril dan mendapat konfirmasi bahwa ayat-ayat tersebut tidak dinasakh.

c. Ayat-ayat yang sudah diseleksi itu hendaknya jangan ditulis kecuali setelah dipresentasikan kepada para sahabat nabi terkemuka, dan mendapat kesaksian dari mereka bahwa ayatayat itu benar-benar ayat-ayat al-Qur`an.

d. Apabila antara anggota tim penulis terjadi perbedaan pendapat dalam cara penulisan ayat, hendaklah dialek Quraysy dijadikan pilihan, karena al-Qur`an diturunkan dengan dialek Quraysy.

e. Qirâ'at-qirâ'at mutawâtirah harus dipertahankan, sedangkan yang tidak mutawâtir tidak dipernekankan untuk ditulis.

f. Lafal yang memuat perbedaan qirấat, dan dapat ditulis dengan satu bentuk, hendaknya ditulis dalam satu bentuk tulisan, seperti firman-Nya: يأيها الذين امنوا إن جاءكم فاسق بنباء فتبينوا.

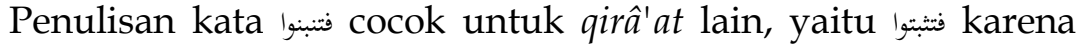
penulisannya tidak memakai titik dan harkat.

g. Lafal yang memuat sisi-sisi qirâ'at dan tidak memungkinkan ditulis dalam satu bentuk tulisan, ditulis dalam satu Mushhaf sesuai dengan satu sisi qirấat, kemudian di Mushhaf yang lain ditulis sesuai dengan qirâ'at yang lain. ${ }^{73}$

Dalam penjelasan Muhammad Subhi i al-Shâlih, Khalifah 'Utsmân memutuskan agar mushaf-mushaf yang beredar adalah mushaf-mushaf yang memenuhi persyaratan sebagai berikut:

a. Harus terbukti mutawâtir, tidak ditulis berdasarkan riwayat ahâad.

b. Mengabaikan ayat yang bacaannya dinaskh dan ayat tersebut tidak diyakini dibaca kembali di hadapan Nabi pada saat-saat terakhir.

73Muhammad Salim Muhaysin, Târîkh al-Qur'ân al-Karîm, (Muassasah Syabab alJami'ah, XX), 145-146; al-Zarqânî, Manâhil al-'Irfân, 257-259 
c. Kronologis surat dan ayat seperti yang sekarang ini, berbeda dengan mushaf Abû Bakr yang susunan suratnya berbeda dengan mushaf Utsmân

d. Sistem penulisan yang digunakan Mushaf mampu mencakupi qirấat yang berbeda dengan lafal-lafal al-Qur`an ketika turun

e. Semua yang bukan termasuk al-Qur`an dihilangkan. ${ }^{74}$

Kebijakan Utsmân ini membuat kerja tim penulis dan penyalin naskah al-Qur`an berhati-hati, teliti dan akurat, serta bisa mengakomodir sisi-sisi qirâ'at yang sahih mata rantai penuturannya dari Rasulullah saw. Setelah kerja tim ini sukses menyalin beberapa naskah otoritatif al-Qur`an, Khalifah Utsmân mengembalikan suhuf Abi Bakr kepada Hafshah r.a. yang dipinjamnya untuk rujukan penyalinan naskah al-Qur`an oleh tim penulis. Salinan-salinan naskah al-Qur'an itu dikirim ke berbagai daerah dengan menyertakan seorang pakar qirâ'at, yaitu:

a. Zayd ibn Tsabit mendapat tugas untuk membacakan alMushhaf al-Madanî.

b. 'Abd ibn al-Sayb, diutus membawa al-Mushhaf al-Makkî dan membacakannya untuk penduduk Mekkah.

c. Mughirah ibn Syihâb, diutus ke Syam untuk membacakan alMushhaf al-Syâmî.

d. Abû 'Abd. al-Rahmân al-Sulamî, diutus ke Kufah untuk membacakan al Mushhaf al-Kîfî.

e. 'Amir ibn Qays, diutus ke Bashrah untuk membacakan alMushhaf al-Bashrî. ${ }^{75}$

Selain itu, Khalifah Utsmân juga memerintahkan kepada seluruh sahabat yang memiliki shahîffah atau shuhuf selain al-Shuhuf alUtsmânî untuk dibakar. Kebijakan ini bertujuan agar perselisihan antar kaum muslimin dalam qirâ'at benar-benar diselesaikan secara tuntas. Dan perlu ditegaskan, fakta sejarah menunjukkan bahwa para Sahabat menerima berbagai kebijakan Khalifah Utsmân tersebut secara ijmâ'.

Demikianlah al-Qur`an telah merupakan suatu kitab yang dinamakan al-Mushhaf pada masa Utsmân bin Affan yang sampai

74Subhi al-Shâlih, Mabâhits, 23.

75Muhaysin, Târîkh al-Qur'ân al-Karîm, 151 
kepada umat Islam sekarang ini. Jadi betapa istimewanya pengumpulan al-Qur`an (jam al-Qur'ân) itu yang dimulai dari masa Nabi saw., masa Khalifah Abu Bakr, hingga masa Khalifah Usman, yang kemudian dikenal dengan Mushhaf 'Utsmânî.76 Al-Qur'an dikumpulkan dari tempat-tempat yang masih sangat sederhana sekali yaitu dari tulang-tulang, pelepah kurma, kulit dan lain-lainnya sampai terkumpul dalam satu master volume, tiada satupun ayatayat yang ketinggalan atau tiada perubahan sedikitpun dari ayatayatnya.

Jauh setelah itu, baru dimulai pencetakan al-Mushhaf dengan menggunakan mesin cetak. Al-Mushhaf dicetak pertama kali di Venesia sekitar tahun 1530 an. Pada tahun 1693 M di Hamburg 1693 M dan pada tahun 1787 M. di Saint Petersbourg Rusia. Di Teheran Iran pada tahun $1828 \mathrm{M}$, kemudian di Tibriz pada tahun $1833 \mathrm{M}$ dan di Leipzig Belanda pada tahun 1839 M. Pencetakan al-Mushhaf di Kairo pada masa Sa 'îd 'Alî di tahun 1923 M merupakan salah satu momen terpenting. Pencetakan al-Mushhaf di Kairo dilakukan dengan perbaikan artistik dan khat melalui supervisi para pakar al-Qur’an Universitas al-Azhar. ${ }^{77} \mathrm{Hal}$ ini menegaskan secara akademik bahwa al-Qur`an yang sampai kepada khalayak sekarang ini benar-benar otentik dan valid sebagaimana yang diturunkan Allah kepada Nabi Muhammad.

Dengan demikian, proses penghimpunan dan pembukuan ayat-ayat al-Qur`an menjadi bukti adanya kesepakatan para shahabat tentang hal itu. Dalam Mushhaf al-Imâm (al-Qur`an standar yang ditulis di masa 'Utsmân) ditulis di dalamnya basmalah di awal alFâtihah, dan di awal setiap surah, kecuali surah Barâ'ah. Demikian juga basmalah tersebut ditulis di mushaf-mushaf yang dikirim ke berbagai negeri yang disalin dari Mushhaf al-Imâm. Hal ini diterima dan diakui secara mutawâtir, sedangkan mereka paham bahwa dalam al-Mushaf tidak boleh ditulis apapun selain al-Qur`an, dan mereka sangat ketat dalam hal ini, hingga nama surah dan penanda-penanda penting pun tidak dimasukkan. Jadi, ketika dalam mushaf tersebut tertulis basmalah di awal surah al-Fâtihah dan surah-surah lainnya, itu

76Subhî al-Shâlihh, Mabâhits fi 'Ulûm al-Qur'ân, Cet. ke-10 (Beirut: Dâr al-'Ilmi li alMalâyîn, 1977), 84-85.

77Ibid., 99-100. 
menunjukkan Basmalah tersebut memang bagian darinya. Keberadaan lafal basmalah dalam al-Qur`an sudah disepakati oleh para sahabat,78 dan oleh karenanya pencantumannya menjadi bukti tak terbantahkan akan kemutawatirannya sebagai ayat al-Qur`an.

Terlepas dari perbedaan mengenai keberadaan basmalah, apakah bagian dari surah atau ayat tersendiri, namun argumentasi ini, menurut al-Sâyis, merupakan bukti yang tak terbantahkan dengan keberadaan basamalah yang ditulis dan al-Mushhaf al-Imâm, baik pada awal surah al-Fâtihah dan berbagai surah lainnya selain surah Barâ'ah. Penulisan demikian juga diikuti oleh berbagai Mushaf lainnya yang dikirim ke berbagai kota, sebagai bukti kemutawatirannya, karena para shahabat bersepakat untuk tidak menulis sesuatu dalam al-Mushaf selain al-Qur`an.79 Fakta demikian merupakan argumentasi dari pandangan mazhab al-Syâfi î, Abû Hanîfah, Hanbalî, dan ulama lain yang sependapat dengan pandangan ketiganya.

Keberadaan berbagai riwayat ahâad yang kontradiktif tidak dapat digunakan untuk menolak atau memasukkan sesuatu teks sebagai ayat al-Qur’an, karena tim penulis al-Qur’an hanya menyandarkan penulisan al-Qur`an dengan sumber periwayatan yang mutawâtir. Dapat ditegaskan bahwa keberadaan lafal basmalah pada awal setiap selain surah Barâ'ah [9] didasarkan pada sumber periwayatan ahâad yang shahih dan ijmâa para shabahat yang dikategorikan sebagai riwayat mutawâtir 'amalî. Usaha demikian merupakan salah satu cara menjaga kemurniannya, sebagai pesan dari firman Allah: Sesungguhnya Kamilah yang menurunkan al-Qur`an, dan sesungguhnya Kami (pulalah) yang memeliharanya. 80

Di samping penilaian Hadits secara kuantitatif dari sisi sanadnya (ta`addut al-ruwah) di atas, Hadits-Hadits yang dijadikan sebagai dasar untuk menolak beradaan lafal basmalah sebagai ayat alQur`an, dapat ditinjau dari muatan petunjuknya (dalâlat al-nashsh),

\footnotetext{
${ }^{78} \mathrm{Al}$-Zarqânî mengatakan bahwa para sahabat telah sepakat terhadap Mushaf Usman dan tidak ada seorang pun dari sahabat yang berkeberatan atau menyangkalnya. Kesepakatan ini tak terjadi kecuali karena pengumpulan ini sifatnya tawqifi. Sebab bila seandainya berdasarkan ijtihad maka para Sahabat tentu akan berpegang teguh pada pendapat mereka yang berlainan. Baca al-Zarqânî, Manâhil al-'Irfân, I, 355.

${ }^{79}$ Al-Sâyis, Tafsîr Âyât al-Ahkâm, Vol. 1, 3.

${ }^{80}$ Q.S. al- Hijr 15: 9.
} 
berisi mengenai tingkah laku Rasulullah ketika memulai shalat dengan bacaan al-hamdulillah. Dan hal ini juga akan menyebabkan perbedaan pendapat mengenai makna dari Hadits tersebut. Semisal Hadits yang menegaskan tentang "mereka memulai shalat dengan alhamd lillâh Rabb al âlamîn" dipahami dalam beberapa pemahaman.

Ibnu Hajar dalam kitabnya Fath al-Bârî menjelaskan bahwa yang dikehendaki dengan kata الصلاة adalah bacaan di dalam shalat. Dalam riwayat Hadits yang diriwayatkan oleh Ibnu Munzîr dan al-

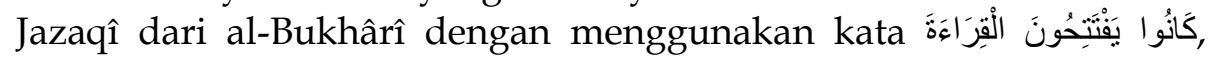
Hadits ini terdapat pula dalam kitab Sunan Abû Dâwûd, Sunan alTurmudzî, Sunan Ibnu Majah, Sunan al-Dârimî, Musnad Ahmad dan Musnad al-Syâfî̂̀ dengan perawi yang berbeda dan redaksi yang berbeda pula, sebagaimana dalam contoh Hadits periwayatan yang lain yang telah disebutkan.

Menurut Ibnu Hajar ada banyak perbedaan perbedaan pendapat dalam memberikan makna lafal bi al-hamdulillâh Rabb al âlamîn, diantaranya ada yang memberikan makna bahwa al-hamd lillâh Rabb al âlamîn adalah surat al-Fâtihah, pendapat ini menurut golongan ulama yang mewajibkan basmalah pada awal surat al Fatihah. Sebagaimana yang dikatakan oleh al-Syâfi'î bahwa surat yang terdapat dalam Hadits ini adalah surat al-hamdulillâh yang memiliki makna surat al-Fâtihhah bukan bacaan lafal al-hamdu lillâhi Rabb al âlamîn. 81

Ada pula yang mengatakan bahwa makna lafal tersebut menggunakan makna dhahirnya Hadits tersebut yaitu bermakna bacaan al-hamd lillâh Rabb al âlamîn. Pendapat ini dipelopori oleh golongan ulama yang tidak memasukkan Basmalah dalam bacaan al Fatihah, karena dalam Hadits yang diriwayatkan oleh Ahmad bin

81Pemahaman demikian didasarkan pada Hadits Nabi Saw. Lihat al-Bukhârî, Shahîh Bukhârî, juz 6, 21:

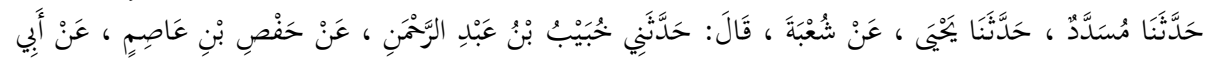

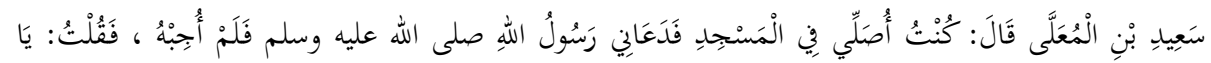

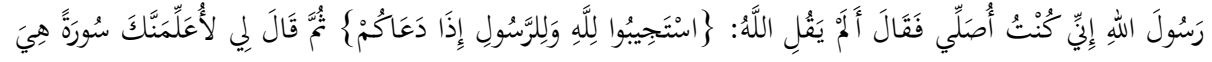

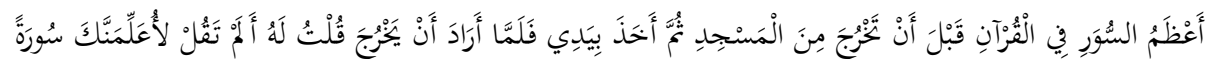

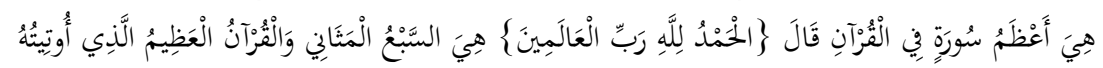


Hanbal disebutkan lafal $\{$ فكانوا يفتحون بالحمد yaitu tanpa menyebutkan basmalah. Terlepas dari perbedaan pendapat tersebut, menurut peneliti dalam pemaknaan Hadits ini ada dua versi yaitu kata alhamdulillâh pada Hadits tersebut bermakna surat al-Fâtihahah, dan ada pula yang memberi makna sesuai dengan makna lahir lafal dengan didukung oleh Hadits yang lain.

Hadits al-Bukharî di atas secara deduktif dapat dipahami bahwa Hadits tersebut mengacu pada hukum fiqh, dalam kaitan ini ulama berbeda pendapat dalam mencermati redaksi Hadits yang kemudian dijadikan sebagai landasan hukum syar' $\hat{\imath}$. Menurut Abu Isa, Hadits yang diriwayatkan oleh al-Bukharî itu adalah Hadits shahîh. Para Sahabat, Tabi'in, dan Tabi' al-tabi'in mengamalkan Hadits ini sesuai dengan redaksi Hadits, yaitu ketika memulai shalat langsung dengan bacaan al-hamdu lillâhi Rabb al 'âlamîn yang dibaca pada awal surat al-Fâtihah. Berbeda menurut al-Syâfi'î yang menyatakan bahwa Rasulullah saw dan Sahabat Abu Bakr, 'Umar dan Utsmân tetap membaca basmalah pada awal surat al-Fâtihah sebelum membaca surah. Jadi maknanya bukan tidak membaca Basmalah, namun tetap membaca basmalah karena itu adalah awal setiap surat dalam alQur`an, jika pada shalat yang dilakukan dengan suara sirrî maka bacaan basmalah juga dibaca sirr, dan sebaliknya jika pada shalat yang mengharuskan membaca jahr, maka basmalah juga harus dibaca jahr.

Dalam kitab Faidh al-Bâri Syarh al-Bukhârî dikatakan bahwa dalam memaknai Hadits ini, mazhab Hanafiyah menyatakan tetap membaca basmalah dengan bacaan sirr, sedangkan mazhab Syâfi'iyyah menyatakan bahwa al-hamd li Allâh Rabb al âlamîn adalah nama dari surat al-Fâtihah, maka bacaan basmalah adalah bagian dari surat alFâtihah dan cara membacanya harus jahr. Menurut al-Hafid al-Zalâ'î bahwa al-hamd lillâh Rabb al âlamîn bukanlah nama surat al-Fâtihah, karena nama surat al-Fâtihah adalah al-hamd saja, sesungguhnya membaca Basmalah baginya adalah sunnah. Sedangkan menurut Mahmûd al-Alûsî membaca basmalah adalah wajib.

Dengan demikian, Hadits-hadits tersebut tidak secara khusus berbicara masalah mutawâtir tidaknya pencantuman basmalah dalam al-Mushhaf. Dan sesungguhnya tidak menjadi kelaziman bahwa penetapan kemutawatiran ayat-ayat al-Qur`an dengan menggunakan riwayat mutawâtir lafzhî. Jika mengikuti pandangan ini, maka 
penetapan kemutawatiran al-Qur’an dapat saja menggunakan periwayatan mutawâtir 'amalî, yaitu ijmâ' Sahabat terhadap hasil pembukuan dan pembakuan al-Qur`an, yakni tidak adanya tulisan dalam al-Qur`an kecuali hanya al-Qur`an, termasuk lafal basmalah. Sementara alasan pencantuman lafal basmalah dalam Mushhaf al-Imâm dan berbagai al-mushhaf yang dikirim ke berbagai daerah hanyalah sebagai tabarruk juga tidaklah dapat diterima, sebagaimana para Sahabat juga tidak menulis kata âmîn sesudah surah al-Fâtihah meskipun membacanya disunnahkan. ${ }^{82}$

Dari uraian di atas dapat dipahami bahwa mazhab al- $\underline{\text { Hanafî, }}$ al-Syâfi'î dan Hanbalî memasukkan lafal basmalah sebagai ayat alQur`an karena didasarkan pada periwayatan mutawâtir ‘amalî, disamping periwayatan ahâad yang bernilai shahîh. Periwayatan mutawâtir 'amalî yang dimaksudkan berkaitan erat dengan proses pengumpulan dan pembukuan al-Qur'an sejak zaman Rasulullah sampai saat ini, yang didasarkan pada ijmak Sahabat.

\section{Penutup}

Dari paparan di atas maka dapat disimpulkan bahwa perdebatan mengenai keberadaan basmalah terjadi karena terdapat riwâyat ahâad yang menginformasikan bahwa Rasulullah tidak membaca basmalah ketika membaca surah al-Fâtihah dalam shalat. Sementara berdasarkan riwâyat ahâd juga ditegaskan bahwa basmalah merupakan ayat pertama dari surah al-Fâtihah.

Fakta kesejarahan pada proses jam 'al-Qur'ân (penghimpunan al-Qur`an) sejak masa Rasulullah, masa Khalifah Abu Bakr sampai pembakuan al-Qur`an pada masa Khalifah 'Utsmân bin 'Affân menegaskan bahwa para Sahabat tidak akan memasukkan atau menolak suatu ayat, jika hanya didasarkan pada riwayat ahâad meskipun kualitasnya shahîh. Dengan demikian penetapan lafal

82Dalam satu Hadits yang diriwayatkan Muslim, dalam Shahîh Muslim, Juz 2, Rasulullah bersabda:

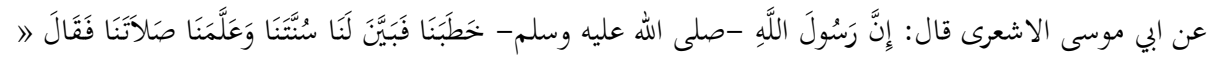

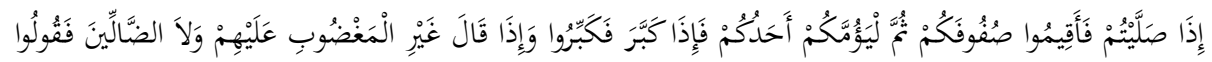

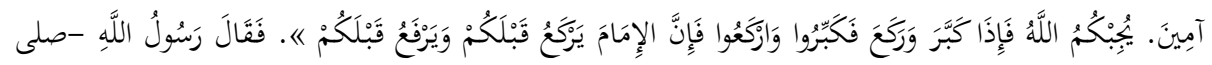

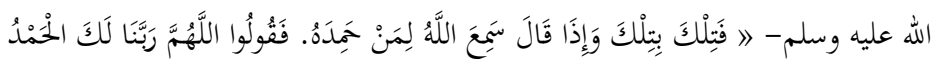


basmalah sebagai ayat al-Qur`an, tidak hanya didasarkan pada riwayat ahâad, tetapi didukung dengan ijmâ' Sahabat terhadap keberadaan Mushhaf Utsmânîa atau dikenal dengan sebutan sumber periwayatan mutawâtir 'amalî.

\section{Daftar Pustaka}

Bâqi, Muhammad Fuâd `Abd al-. al-Mu`jam al-Mufahras li Alfâzh AlQurian al-Karîm. Beirut: Dâr al-Fikr, 1981.

A`zami, M.M. al-. Sejarah Teks Al-Qur`an, dari Wahyu sampai Kompilasi, Terj. Sobirin Solihin dkk. Jakarta: Gema Insani, 2005.

Qâdhî, Abd al-Fattâh bin Abd al-Ghanî al-. al-Farâid al-Hisân fî̀ 'Add Ây al-Qur'ân dan syarahnya Nafầis al-Bayân. al-Madînah alMunawwawah: Dâr bi al-Madînah al-Munawwarah, $1404 \mathrm{H}$.

Abdul Djalal H.A. Ulumul Qur`an. Surabaya: Dunia Ilmu, 1998.

Abdurrahman, Mifdhol. Pengantar Studi Ilmu Hadits. Jakarta: Pustaka Al-Kautsar, 2009.

Âkhir, Abû al-Wafâ Ahmad `Abd al-. al-Mukhtâr min 'Ulûm al-Qur'ân al-Karîm, 2 jilid. al-Mishr: al-Maktab al-Mishrâ al-Hadîts, t.t.

Syuhbah, Muhammad Abu. al-Madkhal Li Dirasat al-Qur'an al-Karim. al-Qâhirah: Dâr al-Sunnah, 1992.

Bombâ, Âdam. Asmâ' al-Qur'ân al-Karîm, cet. ke-1. (Dabî: Markaz Jama`atul Mâjid li al-Tsaqâfah wa al-Turâts, 2009.

Anwar, Moh. Ilmu Musthalah Hadits. Surabaya: Al-Ikhlas, 1981.

Shiddieqy, TM Hasbi Ash-. Pokok-Pokok Ilmu Dirayah Hadits. Jakarta: Bulan Bintang, 1987.

--------, Sejarah dan Pengantar Ilmu Al-Qur'an/Tafsir. Jakarta, Bulan Bintang, 1989.

B. Smeer, Zeid. Ulumul Hadits Pengantar Studi Hadits Praktis. Malang: UIN-Malang Press, 2008.

Baidan, Nashruddin. Metodologi Penafsiran Al-Qur'an. (Yogyakarta: Pustaka Pelajar. 1998.

Banna, Syekh Ahmad ibn Muhammad al-. Ithâf Fudlalâ' al-Basyar bi alQirâ'ât al-Arba at 'Asyar, 2 vol. Beirut: 'Alam al-Kutub, dan alQâhirah: Maktabah al-Kuliyyah al-Azhariyyah, 1987 M./1407 H. 
Bayhaqîi, Abû Bakr bin Husayn bin 'Alî Al-. al-Sunan al-Kubrâ, juz 2. India: Mathba'ah Majles Dâirat al-Ma'âris al-Nidhâmiyah, $1344 \mathrm{H}$.

Bukhârî Muhammad bin Isma'îl Abû `Abdillah al-, al-Jâmi`al-Shahîh al-Mukhtashar, ed. Muhammad Dîb al-Bighâ', 6 vol. Beirut: Dâr Ibn Katsîr, 1987.

Bukhârî, Abû Abd Allâh Muhammad bin Isma'îl bin Ibrâhîm bin alMughîrah al-Ju'fî, al-. Shahîh al-Bukhârî. Beirut: Dâr Thawq alNajâh, 1422 H.

Dârimî, Abû Muhammad Abd Allâh bin Abd Rahmân al-. Sunan alDârimî. T.Tp: Dâr Ihyâ' al-Sunnah al-Nabawiyyah, t.t.

-------. Al-Qur'an dan Terjemahnya. Jakarta: Yayasan Penyelenggara Penterjemah Al-Qur`an , 2007.

Fatchurrahman. Ikhtisar Musthalah Hadits. Bandung: Al-Ma'arif, 1974.

Hady Mufaat, Ahmad, Dirasah Islamiyah tentang Dasar-Dasar Ilmu Hadits dan Musthalahnya. Semarang, Sarana Aspirasi, 1994.

Hamzah, Muchotob. Studi Al-Qur'an Komprehensif. Yogyakarta: Gama Media. 2003.

Hanbal, Ahmad bin Muhammad bin, Musnad Ahmad. al-Qâhirah: Dâr al-Hadîts, t.t.

http://nabildaffa.blogspot.com/2012/01/makalah-Haditsmutawatir-dan-ahad.html, diakses, 3 Desember 2012,

Ichwan, Mohammad Nor. Membahas Ilmu-Ilmu Hadits. Semarang: Rasail Media Group Semrang, 2013.

Ismail, Syuhudi, Pengantar Ilmu Hadits. Bandung: Angkasa,1991.

Kamus Besar Bahasa Indonesia. Jakarta: Pusat Bahasa Departemen Pendidikan Nasional, 2003.

Katsîr, Abû al-Fidâ' Ismâ'îl ibn 'Umar ibn al-Dimasyqî. Tafsîr alQur'ân al-Azhîm, jilid 1. Jîzat: Mu'assasah Qurthubah, t.t.

Khon, Abdul Majid. Ulumul Hadits. Jakarta: Amzah, 2010.

Klaus Krippendorff. Analisis Isi: Pengantar Teori dan Metodologi, terj. Farid Wajdi. Jakarta: Rajawali Press, 1991.

Louis Ma'luf. al-Munjid fî al-Lughat wa al-A lâm. Beirut: Dar alMasyriq, 2008

Mâlikî, Muhammad Alawi al-. Ilmu Ushul Hadits. Yogyakarta: Pustaka Pelajar, 2006.

Mâlikî, Muhammad Ibn Alawi al-, Zubdah al-Itqan fi 'Ulum al-Qur'ân. Jeddah: Dar al-Syuruq, 1986. 
Mudasir. Ilmu Hadits. Jakarta: Pustaka Setia,1997.

Muhammad Salim Muhaysin, Târîkh al-Qur'ân al-Karîm. Muassasah Syabab al-Jami'ah, XX.

Muhammad, Abû 'Îsâ bin 'Îsâ bin Sûrah. Sunan al-Tirmidzî. Mishr:

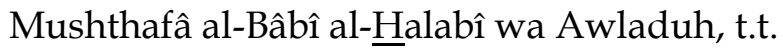

Munawwir, Ahmad Warson. Kamus al-Munawwir, Arab-Indonesia. Yogyakarta: Pondok Pesantren al-Munawwir, 1984.

Nasâ'î, Ahmad bin Syu 'ayb Abu Abd al-Rahman al-. al-Mujtabâ min al-Sunan, ed. Abd al-Fattâh Abû Ghuddah, 8. vol. Halb: Maktab al-Mathbû'ât al-Islâmiyyah, 1986.

Qaththân, Mannâ' al-. Mabâhits fî 'Ulûm al-Qur'ân. Riyadh: Muassasah al-Risâlah, 1976.

Rahman, Fatchur. Ihtisar Musthalahul Hadits. Bandung: Al-Maarif, 1995.

Rahman, Fazlur. Metode dan Alternatif Neomodernisme Islam, terj dan suntingan Taufik Adnan Amal. Bandung: Mizan, 1987.

Sahrani, Sohari. Ulumul Hadits. Bogor: Ghalia Indonesia, 2010.

Shâbûnî, Muhammad 'Alî al-. Tafsîr Âyâtil Ahkâm min al-Qur'ân, cet. ke-1. Beirut: Dâr al-Qur'ân al-Karîm, 2004.

Shâbûnî, Muhammad 'Alî al-. al-Tibyân fi 'Ulûm al-Qur'ân. Makkah: Sayyid Hasan 'Abbâs Syarbatly, 1980.

Shâlihn, Subhî al-. Mabâhits fi 'Ulûm al-Qur'ân, cet. ke-10. Beirut: Dâr al'Ilmi li al-Malâyîn, 1977.

Shihab, M. Quraish. Membumikan Al-Qur'an , Fungsi dan Peran Wahyu dalam Kehidupan Masyarakat. Bandung: Mizan, 1992.

------. Sejarah dan Ulum Al-Qur'an. Jakarta: Pustaka Firdaus, 1999.

Sijistânî, Abû Dâwûd bin Sulaimân bin al-Asy’ats al-, Sunan Abî Dâwûd, 4 vol. Beirut: Dâr al-Kitâb al-`Arabî, t.t. Sunan Abî Dâwû̀d. Riyâd: Matbah al-Ma`ârif, 1424 H.

Soetari AD, Endang. Ilmu Hadits. Bandung: Amal Bakti Press, 1997.

Solahuddin, M. Agus dan Agus Suyadi. Ulumul Hadits. Bandung: Pustaka Setia, 2008.

Subhana \& M. Suderajat. Dasar-Dasar Penelitian Ilmiyah. Bandung: CV. Pustaka Setia, 2005.

Suparta, Munzier. Ilmu Hadits. Jakarta: PT Raja Grafindo Persada, 2002.

Suryadilaga, M. al-Fatih dkk. Metodologi Ilmu Tafsir. Yogyakarta: TERAS, 2005. 
Suyuthi, Jalâl al-Dîn `Abd al-Rahmân al-. al-Itqân fi 'Ulûm al-Qur'ân, Beirut: Dar al-Kutub al'Ilmiyah, 2010.

Syadali, Ahmad dan Ahmad Rafi'i. Ulumul Qur'an I dan II. Bandung: CV. Pustaka Setia, 1997.

Syâfi'î, Abû `Abd Allah Muhammad bin Idrîs al-. Ahkâm al-Qur'ân, 2 juz. Beirut: Dâr al-Kutub al-'Ilmiyyah, $1400 \mathrm{H}$.

Syuhbah, Muhammad Abû. al-Madkhal li Dirâsat al-Qur'ân al-Karîm, jilid 2. al-Qâhirah: Dâr al-Kutub, 1973.

Thahhân, Mahnû̂d al-. Taysîr Mushthalah al-Hadîts. Riyâdl: Maktabah al-Ma`ârif, 1996.

Utsaymin, Muhammad bin Shaleh al-. Ulumul Qur'an. Jakarta: PT. Raja Grafindo Persada. 2000.

Yahyâ bin Syarf al-Nawâwî. al-Adzkâr al-Nawawî, juz 1. Beirut: Dâr alFikr, t.t.

Yaqub, Ali Mustafa. Kritik Hadits. Jakarta: Pustaka Firdaus,1995.

Zamakhsyarî, Mahmûd ibn 'Umar al-Khâwarizmi al-. al-Kasysyâf 'an Haqâiq al-Tanzîl wa 'Uyûn al-Aqâwil fî̀ Wujûh al-Ta'wîl. Beirut: Dâr al-Fikr, 1977.

Zarkasyî, Badr al-Dîn Muhammad bin 'Abd Allah al-. al-Burhân fi 'Ulûm al-Qur'ân, 2 vol. Beirut: Dâr al-Kutub al-'Ilmiyah, 2007

Zarqânî, M. `Abd al-`Adzîm al-. Manâhil al-'Irfân fi 'Ulûm al-Qur'ân. Mesir: 'Isâ al-Bâb al-Halabî, t.t.

Zuhri, Muh. Hadits Nabi Telaah Historis dan Metodologis. Yogyakarta: Tiara Wacana, 1997. 